\title{
Türkiye Maden Sektörü İhracatına Konjonktürel Faktörlerin Etkisi
}

\author{
Alper SÖNMEZ*
}

\begin{abstract}
$\ddot{O} Z$
Bu çalışmanın temel amacı 1992-2013 döneminde Türkiye maden sektörü ihracatında konjonktürel dalgalanma evrelerini ortaya koymak ve bu dalgalanmaların arkasinda yatan ekonomik faktörleri analiz ederek sektör ihracatının nasıl bir gelişme gösterdiğini değerlendirmektir. Bu amaçla sektör ihracatına ilişkin aylık ve yıllık zaman serisi verileri kullanılarak en küçük kareler yöntemiyle doğrusal ve ikinci dereceden regresyon analizleri yapılarak tahmini eğilim (trend) fonksiyonu hesaplanmıştır. Analiz sonuçları tahmini ihracat eğilim fonksiyonunun ikinci dereceden olduğunu ortaya koymuştur. Araştırma sonuçlarına göre sektör ihracatı düzensiz bir şekilde yükselip azalmakta, ayrıca bu dalgalanmaların özellikle 2000 yılı öncesi dönemde istikrar kazandı̆ğ görülmektedir. Bu durum, söz konusu dönemde maden sektörü ihracatının hem içsel hem de dışsal birçok siyasi ve ekonomik faktörden etkilendiğinin ve bir türlü istikrara kavuşamadiğının bir göstergesidir. 2000'li yıllardan sonra ise nispeten daha istikrarlı ve başarıl bir ekonomi yönetimi söz konusu olduğundan içsel konjonktürel dalgalanmalar daha düsüşük seviyede gerçekleşmiştir. Bu yıllarda (2000 sonrası) ortaya çıkan en önemli konjonktürel dalgalanma, dlşsal bir olgu olan 2008 küresel finansal krizi ve bu krizi izleyen bir iki yıl içerisinde Türkiye madencilik sektörü ihracatının yüzde 22 düşmesidir.
\end{abstract}

Anahtar Kelimeler: Madencilik, Madencilik Sektörü, İhracat, Konjonktürel Dalgalanmalar, Türkiye.

JEL Sinıflamast: E32, F14, F17, L72.

\section{The Impact of Cyclical Factors on The Export of Mining Industry in}

\section{Turkey}

\section{ABSTRACT}

The main purpose of the study is to analyze the cyclical fluctuations experienced in the export of mining industry in Turkey for the period over 1992-2013, and evaluate the development processes of the sector's export by analyzing the economic factors behind these fluctuations. For this purpose, by using monthly and yearly time series data related to sector's export, the estimated trend function is calculated by performing linear and quadratic regression analyses by the method of ordinary least squares. The results revealed that the estimated export trend function is a quadratic. According to the findings, it seems that the export of the sector rises and falls irregularly, it is also seen that these fluctuations have gained the stability especially for the pre-2000 period. This situation indicates that the export of the mining sector is affected from both internal and external many political and economic factors and that somehow it has been unable to stabilize in this period. After the 2000s, due to relatively stable and successful economic management, internal cyclical fluctuations are occurred at lower level. The most important cyclical fluctuation occurred in this period (after 2000s) is 2008 global financial crisis, which is an external phenomenon; in subsequent two years the export of the Turkish mining sector declined 22 percent.

Key Words: Mining, Mining Sector, Export, Cyclical Fluctuations, Turkey.

JEL Classification: E32, F14, F17, L72.

\footnotetext{
*Yrd.Doç.Dr., Selçuk Üniversitesi, İ.İ.B.F., İktisat Bölümü, alpersonmez80@ gmail.com
} 


\section{GíRIŞ}

Madencilik sektörü ülke ekonomilerinin ihtiyaç duyduğu temel hammaddelerin sağlanması, birçok sanayi kolunun ilk tedarikçisi olması ve diğer sektörler için önemli bir pazar niteliği taşımasından dolayı küresel olarak özel bir öneme sahiptir $^{1}$ (TOBB, 2008). Tarım sektöründen sonra insan hayatında önemli bir yer tutan ikinci sektördür. Gelişmiş ülkelerin bugün sahip oldukları teknoloji ve refah düzeyinde en etkin rol oynayan faktörlerden biri de hiç kuşkusuz madencilik sektörü olmuştur ${ }^{2}$. TBMM Madencilik Araştırma Komisyon Raporu'na (2010) göre, örneğin Amerika Birleşik Devletleri'nde (ABD) madene dayal1 sanayilerin toplam üretimi 2009 y1lında 27,6 milyar dolar olarak gerçekleşmiş, ve bu sektörün ekonomiye sağladığ 1 toplam katma değer 2,28 trilyon dolar olarak hesaplanmıştır. Aynı rapora göre dünyada yıllık 10 milyar tonun üzerinde (parasal değeri 1,5 trilyon dolar) maden üretilmektedir. Bu veriler madencilik sektörünün dünya ekonomisi için ne kadar önemli olduğunu göstermektedir (TBMM, 2010: 121, 227).

$\mathrm{Bu}$ çalışmadaki temel amacımız Türkiye maden sektörü ihracatında konjonktürel dalgalanma evrelerini ortaya koymak ve bu dalgalanmaların arkasında yatan içsel ve dışsal ekonomik faktörleri analiz etmektir. Bununla birlikte dünya ekonomisinin en önemli sektörlerinden biri olan madencilik sektörünün Türkiye'deki gelişimi hakkında genel bilgi verilerek sektör ihracatının nasıl bir gelişme gösterdiği değerlendirilecektir. Literatürde Türkiye madencilik sektörünü baz alan konjonktürel dalgalanmalar konusunda buna benzer ampirik bir çalışma bulunmamaktadır. Oysa madencilik sektörü ihracatında yaşanan konjonktürel dalgalanmalar, bu sektörün ülke milli gelirine ve istihdamına olan katkıları düşünüldüğünde oldukça önem kazanmaktadır. Gerek çalışmanın sektörel bir analiz olması gerekse konuyla ilgili yapılan yazın taramasında buna benzer bir ampirik araştırmaya rastlanmamış olması çalışmanın önemini ve orijinalliğini ortaya koyması açısından önemlidir.

Çalışmanın bundan sonraki kısmı şu şekilde düzenlenmiştir. İkinci bölümde konjonktürel dalgalanmalar konusunda teorik ve ampirik literatür incelenmiştir. Daha sonra Türkiye madencilik sektörünün tarihsel gelişimi ve yapısal durumu değerlendirilerek üretim ve ihracatına ilişkin istatistikler ortaya konulmuştur. Dördüncü bölümde, 1992-2013 dönemi madencilik ihracatı aylık ve yıllık zaman serisi verileri kullanılarak sektör ihracatının konjonktürel dalgalanmaları analiz edilmiştir. Beşinci bölümde elde edilen bulgular değerlendirilmiştir. Son bölüm ise çalışmanın sonucunu ve politika önerilerini içermektedir.

\footnotetext{
${ }^{1}$ Ekonomik faktörler dişında madencilik sektörüne küresel önem verilmesinin bir diğer nedeni bu sektörün milli güvenlik stratejileri açısından taşıdığı önemdir.

${ }_{2}^{2}$ Dünya madencilik faaliyetlerinde öne çıkan Kanada, ABD, Çin ve Güney Afrika Cumhuriyeti'nin madencilik faaliyetlerine ilişkin detaylı bilgi için lütfen bkz. TBMM (2010).
} 


\section{LITERATÜR ARAŞTIRMASI}

Ekonomik değişkenlerde önceden öngörülemeyen değişmeler sonucu ortaya çıkan inişler ve çıkışlar konjonktür dalgalanmaları olarak adlandırılmaktadır ${ }^{3}$. Bu dalgalanmalar genişleme-tepe-daralma-dip olmak üzere dört aşamadan oluşmakta ve bu dört aşama bir konjonktür devresini meydana getirmektedir. Konjonktürel dalgalanma türleri ise trend (genel eğilim), konjonktür, mevsimlik ve arızi (tesadüfi) dalgalanmalar olmak üzere dört şekilde sinıflandırılmaktadır. Trend bir ekonomide uzun yıllar (20-30 yıl) itibariyle ortaya çıkan hareketlenmeleri ifade ederken, konjonktür dalgalanmaları bir ekonomide veya sektörde görülen döngüsel dalgalanmaları (genişleme-tepe-daralma-dip) ifade etmektedir (Özer ve Taban, 2006). Mevsimlik dalgalanmalar ise ekonomik değişkenlerde on iki ay içerisinde yaşanan mevsimsel olayların etkisi ile ortaya çıkar. Diğer taraftan, arızi dalgalanmalar ise tahmin edilemeyen hesaplanamayan, öngörülemeyen tesadüfi ve olağandışı gerçekleşen olayların sonucunda ekonomik değişkenlerde meydana gelen dalgalanmalardır (Fırat ve Demirtaş, 2012).

Konjonktür dalgalanmalarının ekonomi üzerinde yarattığı etkiler büyük olduğundan iktisat yazınında önemli yer tutmaktadır. Özellikle 1929'da yaşanan büyük buhran sonrası konjonktürel dalgalanmalar ekonomik araştırmaların en ciddi konuları arasında sayılmıştır. Bu dalgalanmaların ekonomi üzerine yarattığ etkiler uluslararası sermaye hareketleri, cari açıklar, kamu açıkları, faizler ve enflasyon gibi iktisadi göstergelerin analizi ile mümkün olmaktadır. Yerli ve yabancı yazında konjonktürel dalgalanmanın kaynakları farklı şekilde incelenmiştir. Tarı ve Kumcu'ya (2005) göre, bu dalgalanmalara Fischer (1993) cari açıkların, Barro (1995) enflasyonun, Yeldan (1996) kısa vadeli sermaye hareketlerinin, Uygur (2000) reel faiz, kamu açıkları ve enflasyonun, Doğruel (2002) ise istikrar politikalarının uygulanmalarındaki sorunların sebep olduğunu ortaya koymuşlardır (Tarı ve Kumcu, 2005: 157). Bir ekonomiye yönelik politika tespiti ve uygulama sürecinde konjonktür dalgalanmaların neresinde olunduğunun ve bu dalgalanmalara yol açan faktörlerin neler olduğunun bilinmesi önem taşımaktadır. Çünkü ekonomilerin dalgalanma evrelerine göre davranışları farklılaşmaktadır (Kabadayı, 2013: 108). Bu nedenle konjonktürel dalgalanmaları analiz etmek ve nedenlerini ortaya koymak doğru iktisat politikaları açısından oldukça önemlidir.

İktisat yazınında konjonktür dalgalanmaları üzerine yapılan teorik çalışmalar oldukça eski tarihlere gitmektedir. Bu dalgalanmaları açıklamaya ve sınıflandırmaya çalışan ilk çalışmalardan birisi Kondratieff ve Stolper 'in (1935) İngiltere üzerine yaptıkları çalışmadır. Bu çalışmada yazarlar, 1700'lü yıllardan itibaren İngiltere'deki fiyatlar ve ücretlerin uzun dönemde değişimlerini inceleyerek üç tür uzun dönemli dalgalanma tespit etmişlerdir. Bir diğer önemli teorik çalışma ise ekonomilerde meydana gelen dalgalanmaların sebebini teknolojik yeniliklere ve girişimcinin rolüne bağlayan Schumpeter'in (1939) çalışmasıdır. Yazara göre teknolojik yenilikler ekonomide en az 3 en fazla 60 yıl

\footnotetext{
${ }^{3}$ Farklı tanımlar için bkz. Mill (1848), Pigou (1927), Haberler, (1937), Hansen (1964).
} 
süren üç tür dalgalanma evresine (3-5 yıl ise kitchin, 7-10 y1l ise juglar ve 48-60 yıl ise kondratief dalgaları) sebep olmaktadır. Ekonomide ortaya çıkan dalgalanmaların nedenini göç ve demografik değişkenlere bağlayan ve bu dalgalanmaların 15-20 yıllık sürelerle gerçekleştiğini (kuznets dalgası) öne süren Kuznets'in (1930) çalışması ise bir diğer önemli teorik çalışmadır. Aydoğuş vd. (2009) bu teorik çalışmaları ayrıntılı tarihsel bilgiler çerçevesinde ele almaktadır. İktisat yazınında konjonktürel dalgalanma teorileri beş başlık altında incelenmektedir. $\mathrm{Bu}$ teoriler klasik yaklaşım teorileri ve keynesci konjonktür teorileri, parasal teoriler, yeni klasik teoriler, yeni keynesci ve politik konjonktür teorileridir (Firat ve Demirtaş, 2012).

Konjonktür dalgalanmaları üzerine yapılan uluslararas1 ampirik çalışmaları incelediğimizde Burns ve Mitchell (1946) çalışması ön plana çıkmaktadır. Konjonktür konusundaki ampirik çalışmalar bu yazarlar tarafından başlatılmıştır. Yazarlar dört ülkeye ait (ABD, Almanya, Fransa ve İngiltere) çeşitli zaman serisi verilerini kullanarak bu serilerin nasıl hareket ettiklerini çeşitli matematiksel yöntemlerle hesaplamışlar ve ilk defa konjonktür dalgalanmalarının mevsimsel ve arizi faktörleri içerdiğini ortaya koymuşlardır. Uluslararası iktisat yazınında çeşitli değişkenlere ilişkin haftalık, aylık ve yıllık zaman serisi verilerini kullanarak serilerin dalgalanma boyutunu matematiksel yöntemler ile analiz eden çok sayıda ampirik çalışma göze çarpmaktadır. ABD ekonomisinde işsizlik oranlarında meydana gelen dalgalanmaları yıllık serilerle analiz eden Nefçi (1984), ABD ekonomisinin gösterdiği daralma ve genişlemeleri üç aylık verilerle ortaya koyan Diebold ve Rudebusch (1996), New York Borsasında işlem gören enerji ürünlerinin dalgalanmalarını haftalık verilerle analiz eden Alizadeh vd. (2008) iktisat yazınında önemli ampirik çalışmalardır. Bu çalışmalar haricinde, Meksika para birimi pesoda-ki dalgalanmaları analiz eden Bazdresch and Werner (2005), Güney Afrika milli gelirindeki oynaklıkları üç aylık verilerle analiz eden Moolman (2004), aylık verileri kullanarak Japon ekonomisinde ortaya çıkan dalgalanmaları analiz eden Liboshi (2007), Avrupa Birliği’ne üye olan devletlerin menkul kıymetler piyasalarındaki oynaklıkları inceleyen Moore and Wang (2007) ve üç aylık verileri kullanarak yirmi iki ülkenin milli gelir dalgalanmalarını inceleyen Altug ve Bildirici (2010) diğer önemli uluslararası ampirik çalışmalardır.

Ulusal düzeyde konjonktür dalgalanmaları üzerine yapılan ampirik çalışmaları incelediğimizde Karabulut (2005), Akgül vd. (2007), Yamak ve Topbaş (2008), Açıkgöz (2008), Bildirici ve Bozoklu (2010), Bilgili vd. (2012), Kesgingöz (2014) göze çarpan başlıca çalışmalardır. Türkiye ekonomisindeki konjonktürel dalgalanmalara yönelik yapılan çalışmalar makroekonomik bir çerçeve içerisinde kalmaktadır. Bu çalışmalarda sanayi, üretim, faiz oranları, döviz rezervleri, borsa indeksi, milli gelir büyüme oranları, enflasyon, doğrudan yabancı sermaye yatırımları vb. zaman serileri kullanılarak Türkiye ekonomisinin konjonktür dönemleri analiz edilmiştir.

Türkiye'de politik gelişmelerin konjonktür dalgaları üzerindeki etkilerini araştıran teorik çalışmalarda vardır. Bu teoriye göre Türkiye'de iktidar partileri 
yeniden seçilebilmek için ekonomiyi kendi çıkarları doğrultusunda manipüle etmekte ve bu da ekonomik krizlere neden olabilmektedir. Politikanın ekonomi üzerindeki etkisinin araştırıldığı çalışmalar politik konjonktür dalgalanmaları literatürünü oluşturmaktadır (literatür hakkında detaylı bilgi için bkz. Sayan ve Berument, 1997; Onur, 2001; Akçoraoğlu ve Yurdakul, 2004; Tarı ve Kumcu, 2005; Sezgin, 2007; Özkan ve Tarı, 2010; Fırat ve Demirtaş, 2012). Akçoraoğlu ve Yurdakul (2004), 1987-2003 dönemi için yapmış oldukları çalışmada, büyüme, enflasyon ve bütçe açıkları değişkenlerini kullanarak Türkiye'de politik konjonktür dalgalanmaların olup olmadığını araştırmışlardır. Araştırmacıların bulguları genel seçimlerin yapıldığı dönemlerde bütçe açıklarının arttığını, seçim dönemlerinin enflasyon ve iktisadi büyüme üzerinde bir etkisi olmadığını ortaya koymuştur. Tarı ve Kumcu (2005) 1983-2003 dönemi verilerini kullanarak Türkiye'de makroekonomik istikrarsızlık ve büyüme arasındaki ilişkiyi incelemişlerdir. Çalışma sonuçları, kısa vadeli sermaye hareketleri, cari açıklar, kamu açıkları, reel faiz ve enflasyonun ekonomik büyümeyi istikrarsız kıldığını göstermektedir. Sezgin (2007)'in 1950-2003 yıllarını kapsayan çalışmasının bulguları, Türkiye'de ekonomik büyümenin siyasi seçimlerden olumsuz etkilendiğini, kamu harcamaları ve bütçe açıklarının seçim dönemlerinde arttı̆̆ını ve bu durumun politik konjonktürel dalgalanmalara yol açtığını ortaya koymaktadır. Özkan ve Tarı (2010) yapmış oldukları çalışmalarında makroekonomik değişkenler (GSYH, para arzı ve kamu harcamaları gibi) kullanarak Türkiye'de 1985 sonrası altı milletvekili genel seçimleri döneminde politik konjonktürel dalgalanma olup olmadığını incelemiştir. Araştırmacıların bulguları genel olarak değerlendirildiğinde, politik konjonktürel dalgalanmaların en belirgin olduğu seçim döneminin 1987 seçimleri olduğu, 2002 ve 2007 seçimlerinde bu dalgalanmaların etkisinin diğer dönemlere göre daha zayıf olduğu görülmektedir. Fırat ve Demirtaş'ın (2012) çalışması Türkiye ekonomisinde 1980-2000 yılları arasında yaşanan konjonktürel dalgalanmaları analiz ederken, Kesgingöz'ün (2014) çalışması Türk sanayisinde yaşanan konjonktürel dalgalanmaların makro ekonomik nedenlerine ilişkin ayrıntılı bir değerlendirme ortaya koymaktadir.

\section{TÜRKIYY MADEN SEKTÖRÜNÜN YAPISAL DURUMU A. Sektörün Tarihsel Gelişimi}

Türkiye madenciliğinin ve madencilik sektörünün geçirdiği tarihi evreler üç ana dönem altında toplanabilir: tarihi çağda madencilik, Osmanlı döneminde ve cumhuriyet döneminde madencilik ${ }^{4}$ (Turan, 1981: 47). Madencilik konusunda en önemli atılımlar Cumhuriyet sonras1 1923-1945 döneminde, özellikle 1932 yılından sonra devletçilik politikası altında gerçekleştirilmiştir. Bu dönemde madencilik yatırımları Sümerbank tarafından finanse edilmiş, 1935 yılında Etibank ve Maden Tetkik ve Arama (MTA) Enstitüsü kurulmuş, Zonguldak kömürleri, Ergani bakır gibi önemli madencilik üniteleri kamulaştırılmış, dağınık

\footnotetext{
${ }^{4}$ Türkiye'de madenciliğin tarihçesi, Osmanlı ve cumhuriyet dönemi madencilik politikaları hakkında detaylı bilgi için bkz. Turan (1981); Turan (1983); Türkiye'de Madenciliğin Tarihçesi ve MTA (1985); Kepenek (1987); Boratav (1988); Kartalkanat (1991); Tamzok (2005); Tamzok (2008); Kepenek ve Yentürk (2011).
} 
ve ilkel yöntemlerle çalıştırılan madenlerde merkezi denetim sağlanmıştır (Turan, 1981: 56). Bu dönemde hazırlanan birinci ve ikinci beş yıllık kalkınma planlarında madencilik sektörü yatırımlarına ve politikalarına büyük önem verilmiştir ${ }^{5} .1945$ yılından sonra ki dönemlerde ise genel olarak kamu ağırlıklı yapıdan özel sektör ağırlıklı yapıya dönüşüm süreci başlamıştır. Özellikle 1980'li yıllardan itibaren bu politika hız kazanmış, madencilik kuruluşlarının özelleştirilmesi ile özel sektörün ön plana alındığı ve ihracata odaklı ekonomi politikaları hayat geçirilmeye başlanmıştır (Tamzok, 2005: 17; TBMM, 2010).

Türkiye madencilik sektöründe işyeri sayısının büyük bir kısmı özel kesime aittir. Ancak işyeri sayısına ilişkin bu dağılım madencilik sektöründe ağırlığın özel kesimin elinde olduğunu göstermiyor. İşyeri başına çalışan sayısı, satışlar, sermaye yoğunluğu ve teknoloji açısından incelendiğinde kamunun madencilik sektöründe hâkim olduğu görülüyor (Kepenek ve Yentürk, 2011: 439). Başka bir deyişle Türkiye madencilik sektörü kamu kuruluşları ağırlıklı bir yapıya sahiptir diyebiliriz. Ancak yakın zamana kadar devam eden bu yap 2002 sonrası dönemde gerçekleştirilen özelleştirmeler (Eti Maden İşletmeleri, Türkiye Kömür İşletmeleri vb.) neticesinde değişmektedir. Sonuç itibariyle bugün Türk madenciliğinin kurumsal yapısının kamu-özel ayrımı olmaksızın küçük ve orta ölçekli işletmelerden oluştuğu ifade edilebilir (FIRAT Kalkınma Ajansı, 2011: 15-16).

Günümüzde dünya maden rezervlerinde önemli paylara sahip ve madencilik sektöründe önemli rol oynayan başlıca altı ülke ABD, Çin, Güney Afrika, Kanada, Avustralya ve Rusya'dır ${ }^{6}$. Toplam üretim değeri itibariyle ise Türkiye dünyada 132 ülke arasında 28 , maden çeşitliliği açısından ise 10'uncu sırada bulunmaktadır (Ekonomi Bakanlı̆̆ı, 2012: 1). Türkiye'nin maden potansiyelini değerlendirdiğimizde çeşitlilik açısından dünyanın zengin ülkelerinden biri olduğunu görüyoruz ${ }^{7}$, ancak gerek toplam rezerv gerekse bu rezervlerin kalitesi açısından Türkiye'nin maden potansiyelinin çok yüksek olmadığ1 görülmektedir (TOBB, 2008: 1). Buna rağmen ülkemizin, maden rezervleri ve çeşitliliği bakımından kendi kendine kısmen yeterli olan ülkeler arasında yer aldığı söylenebilir ${ }^{8}$ (TBMM, 2010: 126; Enerji ve Tabii Kaynaklar Bakanlı̆̆1, 2013: 55).

\section{B. Madencilik Sektöründe Üretim}

Özellikle 2002 yılı sonrası Türkiye madencilik sektörü hızla gelişerek 16 milyar TL ciroya, 2500 işletme sayısına ve yaklaşı 120.000 kişilik istihdam kapasitesine ulaşarak Türkiye sanayinde önemli bir sektör konumuna gelmiştir.

\footnotetext{
${ }^{5}$ Madencilik sektörüne ilişkin bu dönemde izlenen temel politikalar şu ana başlıklar altında özetlenebilir: İmalat sanayinin üretim faaliyetleri için gereksinim duyduğu hammaddenin en verimli, ucuz ve güvenli biçimde tedarik edilmesi, çıkarılan madencilik ürünlerinin yurt içinde işlenerek ekonomiye sağlanan katma değerin artırılması, ülkemiz maden kaynaklarının geliştirilmesi ve çeşitlendirilmesine yönelik arama faaliyetlerine öncelik verilmesi. ${ }^{6}$ Dünya madenciliğinin mevcut durumu, madencilik faaliyetleri gelişme ve eğilimler için lütfen bkz. TBMM (2010: 227-251); Kalkınma Bakanlığı (2015).

${ }^{7}$ Ülkemiz maden kaynakları açısından oldukça zengindir. Dünya çağında uluslararası ticareti yapılan yaklaşık 90 çeşit madenden 77'si ülkemizde bulunmaktadır.

${ }^{8}$ Sektörün Dünyada, Avrupa Birliği’nde ve Türkiye'de ki mevcut durumu hakkında detaylı bilgi için bkz. DPT (2007); TBMM (2010); Kalkınma Bakanlığı (2015).
} 
Madencilik sektörünün gayri safi yurtiçi hasıla (GSYH) içindeki değeri de 2002 yılında 1,9 milyar dolardan 2013 yılında 11,5 milyar dolara yükselmiştir. Sektörün Türkiye GSYH içindeki payı da aynı dönemde yükselerek ortalama yüzde 1,4 (2013) seviyelerine çıkmıştır. Madencilik ve madene dayalı sanayi birlikte düşünüldüğünde oluşan katma değerin milli gelir içindeki payı yüzde 12'yi bulmaktadır (Ekonomi Bakanlığı, 2012, 1, 8; Enerji ve Tabii Kaynaklar Bakanlığı, 2013, 56-58). Madenciliğin milli gelirdeki payı gelişmiş ülkelerde ortalama yüzde 4, dünya genelinde ise yüzde 2'dir. Örneğin Almanya'da yüzde 4, ABD'de yüzde 5, Kanada'da yüzde 8 , Avustralya'da yüzde 9 civarındadır. 2000'li yıllardan sonra Türkiye ekonomisinin gösterdiği kayda değer gelişmeye rağmen madenciliğin Türkiye milli geliri içerisindeki payı dünya ortalamalarının altında kalmaktadır. Bu durumun arkasında yatan birçok neden olmakla birlikte en önemli etken sektörün taşıdığı yapısal sorunlardır ${ }^{9}$ (TBMM, 2010; TMMOB, 2011: 4).

\section{Madencilik Sektöründe Dış Ticaret}

Türkiye maden sektörü ihracatı 1990-2000 arası y1llarda yıllık 233 milyon dolar (1993) ile 400 milyon dolar (2000) arasında gerçekleşmiştir. 2000 sonrası dönemde madencilik sektöründe görülen en önemli gelişme, ihracatın hızlı bir artış sürecine girmesi olmuştur ${ }^{0}$. Küresel piyasalarda 2000'li yıllar sonrası Çin'in maden piyasalarında yükselen talebi ve ticari konumu dünya madencilik pazarında daha önce hiç olmadığı kadar pozitif gelişmelere yol açmıştır. Bu gelişmelere paralel olarak ülkemizde de sektör ihracatının 2003 yılından itibaren önemli bir ivme kazandığı ve 2009'a kadar yüzde 262 büyüme kaydettiği görülmektedir. 2000-2009 yılları arası sektör ihracatının Türkiye toplam ihracatı içindeki oranı yıllar itibariyle değişmekle birlikte ortalama yüzde 1 ile yüzde 2,4 arasında değişmektedir. Maden sektörüne yönelik küresel talep artışına paralel olarak, 2009 küresel finansal kriz dönemi hariç (2,3 milyar dolar), Türkiye maden sektörü ihracatı süreklilik kazanan bir ivme yakalamış ve 2013 yılında (5 milyar dolar ile) Türkiye toplam ihracatı içinde yüzde 3,3 oranı ile rekor kırmıştır. Mermer ve doğal taş Türkiye madencilik sektörünün toplam ihracatı içerisinde yüzde 50 ile en önemli paya sahip olan iki rezervdir. Türkiye'nin ihracat yaptığı en önemli ülke ise toplam ihracat içerisinde yüzde 40 paya sahip Çin'dir. Çin'i yüzde 5 ile İtalya ve yüzde 4 ile Belçika izlemektedir (DPT, 2007: 40-49; TBMM, 2010: 144-147; TMMOB, 2011; Enerji ve Tabii Kaynaklar Bakanlığı, 2013: 56-58; Kalkınma Bakanlığı, 2015: 26-29).

Türkiye'nin maden ithalatını incelediğimizde ise özellikle 2001 yılından sonra ithalatın ihracattan daha hızlı bir artarak maden ihracatını ikiye katladığını görmekteyiz. 2000 yılında 900 milyon dolar civarında olan maden ürünleri ithalatı

\footnotetext{
${ }^{9}$ Sektörün GZFT analizi (Güçlü yanları, Zayıf yanları, Fırsatları ve Tehditleri), yapısal sorunları ve çözüm önerileri için lütfen bkz. DPT (2007); TOBB (2008); TBMM (2010); TMMOB (2011); Kalkınma Bakanlığı (2015).

${ }^{10}$ İhracattaki bu ciddi gelişmenin nedenleri olarak o dönemde dünya ekonomisinde yaşanan canlanma ve buna bağlı olarak Türkiye'nin temel ihraç ürünlerine olan talebin artması gösterilebilir. Ayrıca Türkiye ekonomisinin ihracatını artırmaya yönelik alınan politik kararlar ve fiyat artışları da bu gelişmelerin yaşanmasında birinci derecede etkili olmuştur.
} 
2009 yılında 4,5 milyar dolar ile rekor seviyeye ulaşmıştır. Aynı dönemde maden ithalatının toplam ithalat içindeki payı da yüzde 1,2 (2001) ile yüzde 3 (2009) arasında değişmiştir. 2000 sonrası dönemde ihracatın ithalatı karşılama oranı ise en yüksek yüzde 69 (2001) ile en düşük yüzde 37 (2009 yılı, tarihinin en düşük seviyesinde) arasında gerçekleşmiştir (TBMM, 2010: 147). Bu istatistikler Türkiye'nin net maden ithalatçısı konumunda olduğunu göstermektedir.

\section{ARAŞTIRMA SORULARI, YÖNTEM VE ANALIZZ}

$\mathrm{Bu}$ çalışmada ki temel araştırma sorumuz, "Türkiye madencilik sektörü ihracatını etkileyen konjonktürel dalgalanmalar var mıdır?”. Bunu destekleyen iki alt araştırma sorularımız ise; "eğer konjonktürel dalgalanmalar var ise hangi dönemlerde ortaya çıkmıştır?" ve "bu dalgalanmalara yol açan içsel ve dışsal ekonomik faktörler nelerdir?”. Bu araştırma sorularını test etmek amaciyla, Türkiye' de 1992-2013 dönemi ele alınmıştır. Bu dönemler itibariyle sektörün ihracatında konjonktürel dalgalanmaların var olup olmadığı aylık ve yıllık zaman serisi verileri kullanılarak en küçük kareler yöntemiyle (OLS) doğrusal ve ikinci dereceden regresyon analizleri yapılarak analiz edilecektir.

\section{A. Yıllık Konjonktür ve Arızi Faktörler Etki Analizi}

Türkiye maden sektörü ihracatına konjonktür ve arızi (KA) faktörlerin etkisini analiz etmek için, 1992-2013 yıllar arası TÜİK dış ticaret nominal ihracat zaman serisi veri seti (dış ticaret istatistikleri veri tabanı, ISIC Revize 3 sınıflamasına göre, ABD doları) kullanılmıştır.

Söz konusu veri setini enflasyonun etkilerinden arındırmak için ise sektöre ilişkin TÜİK ihracat birim değer endeksi veri setinden (diş ticaret ihracat endeksleri, ISIC Revize 3'e göre diş ticaret endeksleri, ABD doları) yararlanılmıştır. Tablo 1 maden sektörüne ilişkin hesaplanan aylık ve yıllık reel ihracat değerlerini göstermektedir (nominal ihracat verisi 1992 yılı fiyatları temel alınarak deflate edilmiştir).

Tablo 1: 1992-2013 Dönemi Türkiye Maden Sektörü

Reel İhracat Değerleri $\left(Y_{t}\right)($ Milyon \$, 1992=100)

\begin{tabular}{|c|c|c|c|c|c|c|c|c|c|c|c|c|c|}
\hline \multicolumn{14}{|c|}{ Ay } \\
\hline YII & 1 & 2 & 3 & 4 & 5 & 6 & 7 & 8 & 9 & 10 & 11 & 12 & Yillık \\
\hline 1992 & 28 & 18 & 21 & 18 & 22 & 24 & 28 & 16 & 33 & 18 & 24 & 18 & 267 \\
\hline 1993 & 16 & 13 & 16 & 15 & 17 & 16 & 29 & 29 & 16 & 26 & 27 & 23 & 240 \\
\hline 1994 & 14 & 19 & 24 & 20 & 17 & 21 & 20 & 28 & 29 & 24 & 32 & 34 & 281 \\
\hline 1995 & 21 & 20 & 25 & 30 & 23 & 31 & 39 & 35 & 31 & 18 & 45 & 51 & 368 \\
\hline 1996 & 23 & 31 & 33 & 29 & 26 & 32 & 39 & 26 & 43 & 33 & 19 & 33 & 367 \\
\hline 1997 & 29 & 33 & 37 & 27 & 57 & 22 & 48 & 43 & 38 & 39 & 40 & 51 & 464 \\
\hline 1998 & 40 & 34 & 42 & 42 & 38 & 46 & 33 & 44 & 33 & 37 & 22 & 40 & 449 \\
\hline 1999 & 21 & 32 & 41 & 54 & 46 & 44 & 47 & 38 & 44 & 39 & 46 & 48 & 499 \\
\hline 2000 & 39 & 28 & 43 & 52 & 46 & 55 & 48 & 41 & 39 & 39 & 42 & 46 & 518 \\
\hline 2001 & 32 & 27 & 38 & 34 & 40 & 54 & 61 & 33 & 34 & 45 & 51 & 27 & 472 \\
\hline 2002 & 36 & 21 & 40 & 42 & 42 & 46 & 57 & 48 & 40 & 55 & 55 & 30 & 508 \\
\hline 2003 & 35 & 28 & 52 & 39 & 48 & 48 & 57 & 60 & 54 & 59 & 56 & 44 & 581 \\
\hline 2004 & 48 & 48 & 50 & 53 & 66 & 50 & 73 & 49 & 56 & 68 & 62 & 64 & 686 \\
\hline 2005 & 54 & 44 & 61 & 60 & 79 & 70 & 63 & 72 & 68 & 71 & 57 & 82 & 780 \\
\hline 2006 & 52 & 60 & 58 & 85 & 84 & 101 & 87 & 83 & 83 & 78 & 92 & 107 & 976 \\
\hline 2007 & 82 & 66 & 87 & 80 & 86 & 116 & 112 & 134 & 113 & 106 & 104 & 108 & 1,205 \\
\hline 2008 & 96 & 105 & 79 & 110 & 128 & 134 & 139 & 167 & 147 & 111 & 111 & 81 & 1,424 \\
\hline 2009 & 86 & 49 & 80 & 99 & 100 & 128 & 158 & 143 & 154 & 120 & 134 & 197 & 1,462 \\
\hline
\end{tabular}




\begin{tabular}{llllllllllllll}
\hline $\mathbf{2 0 1 0}$ & 118 & 158 & 134 & 201 & 200 & 191 & 206 & 183 & 157 & 193 & 147 & 175 & 2,061 \\
$\mathbf{2 0 1 1}$ & 162 & 125 & 138 & 161 & 145 & 168 & 187 & 192 & 161 & 170 & 189 & 194 & 1,991 \\
$\mathbf{2 0 1 2}$ & 160 & 133 & 149 & 174 & 190 & 237 & 206 & 177 & 197 & 180 & 243 & 214 & 2,255 \\
$\mathbf{2 0 1 3}$ & 213 & 221 & 184 & 189 & 272 & 223 & 232 & 218 & 227 & 208 & 234 & 218 & 2,639 \\
\hline
\end{tabular}

Kaynak: Nominal ihracat (\$) verisi: TÜİK, diş ticaret istatistikleri veri tabanı, ISIC Revize 3 sınıflamasına göre dış ticaret. İhracat birim değer endeksi (ABD doları): TÜiK, dış ticaret aylık endeksleri, ISIC Revize 3'e göre diş ticaret endeksleri $(2010=100)$.

Not: 1992-1996 yılları için maden sektörüne ilişkin ihracat birim değer endeksinde veri eksikliği nedeni ile beş sektöre ilişkin (tarım ve ormancılık, balıkçılık, madencilik ve taş ocakçılığı, imalat, atık ve hurdalar) genel endeksler, 1997-2013 yılları için ise madencilik ve taş ocakçılığ sektörüne ilişkin ihracat endeksleri kullanılmıştır.

Sektöre ilişkin yıllık reel ihracat eğilim fonksiyonunu belirlemek için en küçük kareler yöntemi kullanılarak doğrusal ve ikinci dereceden regresyon analizi yapılmıştır ${ }^{11}$. Regresyon sonuçları Tablo 2'de görülmektedir. Buna göre ikinci dereceden regresyon analizinde tahmini $\mathrm{Y}$ standart hata değeri daha küçük olduğundan $(118.844<312.416)$ tahmini reel ihracat eğilim fonksiyonu aşağıda (1) nolu denklemde belirtildiği şekilde hesaplanmıştır.

$$
\mathrm{Y}^{\prime} \mathrm{t}=474.830-75.923 \mathrm{X}_{1}+7.708 \mathrm{X}_{2}
$$

Tablo 2: Regresyon Analiz Sonuçları

\begin{tabular}{lrcc}
\hline & Doğrusal regresyon analizi & İkinci dereceden regresyon analizi \\
\hline Sabit & -234.345 & $474.830^{* * *}$ & \\
Standart Hata & 312.416 & 118.844 & \\
R Kare & 0.823 & 0.976 & \\
Gözlem Say1s1 & 22 & 22 & \\
Serbestlik Derecesi & 20 & 19 & \\
& & & $7.708^{* * *}$ \\
X Katsayıları & $101.371^{* * *}$ & $-75.923^{* * *}$ & 0.706 \\
Standart Hata & 10.499 & 16.722 & 0.000 \\
P-value & 0.000 & 0.000 & \\
\hline
\end{tabular}

Regresyon Denklemi: $\mathrm{Y}^{\prime} \mathrm{t}=-234.345+101.371 \mathrm{X}_{1} \quad \mathrm{Y}^{\prime} \mathrm{t}=474.830-75.923 \mathrm{X}_{1}+7.708 \mathrm{X}_{2}$

Not: 1992 yılı değerine 1 değeri $(X=1)$ verilmiştir ve orijin 30 Haziran 1992 olarak alınmıştır. İkinci derece regresyon denkleminde $\mathrm{X}_{2}$ değişkeni $\mathrm{X}_{1}$ değişkeninin karesidir $\left(\mathrm{X}_{2}=\mathrm{X}_{1}{ }^{2}\right)$. *** $\mathrm{p}<0.01$, ** $\mathrm{p}<0.05, * \mathrm{p}<0.10$

Reel ihracat verisi gözlem değerleri tahmini eğilim fonksiyonu sonucu hesaplanan tahmini ihracat eğilim değerlerine (Y’t) bölünüp yüz ile çarpılarak sektöre ilişkin KA faktörler verisi elde edilmiştir (Tablo 3).

Tablo 3: Maden Sektörü İhracatına Konjonktür ve Arızi Faktörler Yıllık Etkisi (KA)

\begin{tabular}{rrrr}
\hline Yll & $\begin{array}{r}\text { Reel İhracat (Yt) } \\
\text { Milyon \$ }\end{array}$ & $\begin{array}{r}\mathbf{Y}^{\prime} \mathbf{t}^{\mathbf{a}} \\
\text { Milyon \$ }\end{array}$ & $\begin{array}{r}\mathbf{K A}^{\mathbf{b}} \\
(\mathbf{\%})\end{array}$ \\
\hline $\mathbf{1 9 9 2}$ & 267 & 407 & 65.67 \\
$\mathbf{1 9 9 3}$ & 240 & 354 & 67.83 \\
$\mathbf{1 9 9 4}$ & 281 & 316 & 88.64 \\
$\mathbf{1 9 9 5}$ & 368 & 294 & 124.91 \\
$\mathbf{1 9 9 6}$ & 367 & 288 & 127.36 \\
$\mathbf{1 9 9 7}$ & 464 & 297 & 156.39 \\
\hline
\end{tabular}

\footnotetext{
11 Zaman serisi modeli dört bileşeni içermektedir; eğilim, konjonktür, mevsimsel etkiler ve arızi bileşenler. Zaman serilerinin analiz yöntemleri hakkında detaylı bilgi için bkz. Mann, 1995; Kazmier, 2003; Weiers, 2007.
} 


\begin{tabular}{lrrr}
\hline $\mathbf{1 9 9 8}$ & 449 & 321 & 139.89 \\
$\mathbf{1 9 9 9}$ & 499 & 361 & 138.25 \\
$\mathbf{2 0 0 0}$ & 518 & 416 & 124.48 \\
$\mathbf{2 0 0 1}$ & 472 & 486 & 97.13 \\
$\mathbf{2 0 0 2}$ & 508 & 572 & 88.69 \\
$\mathbf{2 0 0 3}$ & 581 & 674 & 86.27 \\
$\mathbf{2 0 0 4}$ & 686 & 791 & 86.76 \\
$\mathbf{2 0 0 5}$ & 780 & 923 & 84.50 \\
$\mathbf{2 0 0 6}$ & 976 & 1,070 & 91.17 \\
$\mathbf{2 0 0 7}$ & 1,205 & 1,233 & 97.71 \\
$\mathbf{2 0 0 8}$ & 1,424 & 1,412 & 100.84 \\
$\mathbf{2 0 0 9}$ & 1,462 & 1,606 & 91.04 \\
$\mathbf{2 0 1 0}$ & 2,061 & 1,815 & 113.55 \\
$\mathbf{2 0 1 1}$ & 1,991 & 2,040 & 97.59 \\
$\mathbf{2 0 1 2}$ & 2,255 & 2,280 & 98.92 \\
$\mathbf{2 0 1 3}$ & 2,639 & 2,535 & 104.08 \\
\hline
\end{tabular}

Not: a: İkinci derece eğilim fonksiyonuyla elde edilen tahmini y1llık reel ihracat değerleri. 1992 yılına $X=1$ değeri verilmiştir. Orijin: 30 Haziran 1992. b: Konjonktür ve arızi faktörler $(\mathrm{KA})=\left[\left(\mathrm{Yt}_{\mathrm{t}} / \mathrm{Y}^{\prime} \mathrm{t}\right) \mathrm{x} 100\right]$.

\section{B. Aylık Konjonktür, Arızi ve Mevsimsel Faktörler Etki Analizi}

Trend ve konjonktür dalgalanmaları ekonomik faaliyetlerin uzun dönemli analizi için önemlidir. Oysa mevsim dalgalanmaları kısa dönemli analizler ve planlamalar için gereklidir. $\mathrm{Bu}$ nedenle madencilik sektörü ihracatında yıl içerisinde mevsim etkisinin incelenmesi gerekli olmaktadır. Bu bölümde, 19922013 dönemi maden sektörü ihracatına ait aylık serilerde mevsim etkisi araştırılmaktadır. Maden sektörü aylık tahmini ihracat eğilim fonksiyonunu belirlemek için ilk olarak Tablo 1'de hesaplanan aylık reel ihracat zaman serisi verisi kullanılarak en küçük kareler yöntemi ile doğrusal ve ikinci dereceden regresyon analizi yapılmıştır. Regresyon sonuçları Tablo 4'te görülmektedir. Bu sonuçlara göre ikinci dereceden regresyon analizinde tahmini Y standart hata değeri daha küçük olduğundan $(18.288<29.784)$ tahmini reel ihracat eğilim fonksiyonu (2) nolu denklemde belirtildiği şekilde hesaplanmıştır.

$$
\mathrm{Y}^{\prime} \mathrm{t}=37.106-0.491 \mathrm{X}_{1}+0.0045 \mathrm{X}_{2}
$$

Tablo 4: Regresyon Analiz Sonuçları

\begin{tabular}{lccc}
\hline & Doğrusal regresyon analizi & \multicolumn{2}{c}{ İkinci dereceden regresyon analizi } \\
\hline Sabit & $-15.920^{* * *}$ & $37.106^{* * * *}$ & \\
Standart Hata & 29.784 & 18.288 & \\
R Kare & 0.766 & 0.912 & \\
Gözlem Sayıs1 & 264 & 264 & \\
Serbestlik Derecesi & 262 & 261 & \\
& & & \\
X Katsay1ları & $0.705^{* * *}$ & $-0.491 * * *$ & $0.0045^{* * *}$ \\
Standart Hata & 0.024 & 0.059 & 0.0002 \\
P-Value & 0.000 & 0.000 & 0.000 \\
\hline Regresyon Denklemi: & $\mathrm{Y}^{\prime} \mathrm{t}=-15.920+0.705 \mathrm{X}_{1}$ & $\mathrm{Y}^{\prime} \mathrm{t}=37.106-0.491 \mathrm{X}_{1}+0.0045 \mathrm{X}_{2}$
\end{tabular}

Not: 1992 Ocak ayı değerine 1 değeri $(X=1)$ verilmiştir ve orijin Ocak 1992 olarak alınmıştır. İkinci derece regresyon denkleminde $\mathrm{X}_{2}$ değişkeni $\mathrm{X}_{1}$ değişkeninin karesidir $\left(\mathrm{X}_{2}=\mathrm{X}_{1}{ }^{2}\right)$. *** $\mathrm{p}<0.01, * * \mathrm{p}<0.05, * \mathrm{p}<0.10$ 
Tablo 5 ikinci derece eğilim fonksiyonuyla hesaplanmış maden sektörü tahmini aylık ihracat değerlerini (Y't) göstermektedir.

Tablo 5: İkinci Derece Eğilim Fonksiyonuyla Tahmini Aylık Reel İhracat Değerleri (Y’t) (Milyon \$, 1992=100)

\begin{tabular}{|c|c|c|c|c|c|c|c|c|c|c|c|c|}
\hline \multirow[b]{2}{*}{ Yll } & \multicolumn{11}{|c|}{$\overline{\mathbf{A y}}$} & \multirow[b]{2}{*}{12} \\
\hline & 1 & 2 & 3 & 4 & 5 & 6 & 7 & 8 & 9 & 10 & 11 & \\
\hline 1992 & 37 & 36 & 36 & 35 & 35 & 34 & 34 & 33 & 33 & 33 & 32 & 32 \\
\hline 1993 & 31 & 31 & 31 & 30 & 30 & 30 & 29 & 29 & 29 & 28 & 28 & 28 \\
\hline 1994 & 28 & 27 & 27 & 27 & 27 & 26 & 26 & 26 & 26 & 26 & 25 & 25 \\
\hline 1995 & 25 & 25 & 25 & 25 & 25 & 24 & 24 & 24 & 24 & 24 & 24 & 24 \\
\hline 1996 & 24 & 24 & 24 & 24 & 24 & 24 & 24 & 24 & 24 & 24 & 24 & 24 \\
\hline 1997 & 24 & 24 & 24 & 24 & 24 & 24 & 24 & 25 & 25 & 25 & 25 & 25 \\
\hline 1998 & 25 & 25 & 26 & 26 & 26 & 26 & 26 & 27 & 27 & 27 & 27 & 28 \\
\hline 1999 & 28 & 28 & 29 & 29 & 29 & 29 & 30 & 30 & 30 & 31 & 31 & 32 \\
\hline 2000 & 32 & 32 & 33 & 33 & 34 & 34 & 34 & 35 & 35 & 36 & 36 & 37 \\
\hline 2001 & 37 & 38 & 38 & 39 & 39 & 40 & 40 & 41 & 41 & 42 & 43 & 43 \\
\hline 2002 & 44 & 44 & 45 & 46 & 46 & 47 & 48 & 48 & 49 & 50 & 50 & 51 \\
\hline 2003 & 52 & 52 & 53 & 54 & 55 & 55 & 56 & 57 & 58 & 58 & 59 & 60 \\
\hline 2004 & 61 & 62 & 62 & 63 & 64 & 65 & 66 & 67 & 68 & 69 & 69 & 70 \\
\hline 2005 & 71 & 72 & 73 & 74 & 75 & 76 & 77 & 78 & 79 & 80 & 81 & 82 \\
\hline 2006 & 83 & 84 & 85 & 86 & 87 & 88 & 89 & 91 & 92 & 93 & 94 & 95 \\
\hline 2007 & 96 & 97 & 98 & 100 & 101 & 102 & 103 & 104 & 106 & 107 & 108 & 109 \\
\hline 2008 & 110 & 112 & 113 & 114 & 116 & 117 & 118 & 119 & 121 & 122 & 123 & 125 \\
\hline 2009 & 126 & 128 & 129 & 130 & 132 & 133 & 134 & 136 & 137 & 139 & 140 & 142 \\
\hline 2010 & 143 & 145 & 146 & 148 & 149 & 151 & 152 & 154 & 155 & 157 & 158 & 160 \\
\hline 2011 & 161 & 163 & 165 & 166 & 168 & 169 & 171 & 173 & 174 & 176 & 178 & 179 \\
\hline 2012 & 181 & 183 & 184 & 186 & 188 & 189 & 191 & 193 & 195 & 196 & 198 & 200 \\
\hline 2013 & 202 & 204 & 205 & 207 & 209 & 211 & 213 & 215 & 216 & 218 & 220 & 222 \\
\hline
\end{tabular}

Not: Aylık reel ihracatın ikinci dereceden eğilim fonksiyonu: $Y^{\prime} t=37.106-0.491 \mathrm{X}_{1}+0.0045 \mathrm{X}_{2}$. 1992 Ocak ayı değerine $1(X=1)$ değeri verilerek çözülmüştür. Orijin: Ocak 1992.

Maden sektörü ihracatı gözlem değerlerinden eğilim ve konjonktürün etkileri arındırılıp mevsimsel faktörlerin etkilerini ortaya çıkarmak için, gözlem değerleri hesaplanan kendi on ikişerli hareketli ortalamalarına (bkz. Ek 1) bölünüp yüz ile çarpılmıştır. Tablo 6 maden sektörü ihracatının aylık mevsim indeksi değerlerini göstermektedir. Bir sonraki adımda Tablo 6'da elde edilen veriler kullanılarak Mevsim İndeksleri (MI) ve Mevsim İndeksi Katsayısı (MIK) hesaplanmıştır. Mİ ve MiK kullanılarak Düzeltilmiş Mevsim İndeksi (DMİ) değerleri oluşturulmuştur (bkz. Tablo 6) ${ }^{12}$. Maden sektörü ihracatına KA faktörlerin etkisi ise reel ihracat verisinin eğilim fonksiyonu sonucu hesaplanan tahmini ihracat eğilim değerleri ile DMİ katsayılarının çarpımına bölünüp (3) nolu denklemde belirtilen formülle hesaplanmış ve sonuçlar Tablo 7'de verilmiştir.

$$
\mathrm{KA}=\left[\mathrm{Yt} /\left[\left(\mathrm{Y}^{\prime} \mathrm{t} \times \mathrm{DMI}\right) / 100\right]\right] \times 100
$$

\footnotetext{
${ }^{12}$ On iki aylık mevsim indeksi toplamının 1200 olması istenir. 1200 olmadığında mevsim indeksi katsayısı hesaplanarak düzeltilmiş mevsim indeksi değerleri hesaplanır.
} 
Tablo 6: Türkiye Maden Sektörü İhracatının Aylık Mİ Değerleri (\%)

\begin{tabular}{|c|c|c|c|c|c|c|c|c|c|c|c|c|}
\hline \multirow[b]{2}{*}{ Yll } & \multicolumn{12}{|c|}{$\mathbf{A y}$} \\
\hline & 1 & 2 & 3 & 4 & 5 & 6 & 7 & 8 & 9 & 10 & 11 & 12 \\
\hline 1992 & - & - & - & - & - & - & 128 & 76 & 162 & 88 & 118 & 94 \\
\hline 1993 & 85 & 64 & 80 & 80 & 87 & 78 & 142 & 145 & 76 & 123 & 124 & 104 \\
\hline 1994 & 65 & 88 & 109 & 92 & 75 & 94 & 85 & 115 & 120 & 96 & 127 & 130 \\
\hline 1995 & 77 & 70 & 89 & 105 & 80 & 102 & 126 & 112 & 96 & 56 & 137 & 157 \\
\hline 1996 & 71 & 96 & 101 & 86 & 79 & 102 & 126 & 85 & 136 & 105 & 58 & 98 \\
\hline 1997 & 87 & 94 & 106 & 77 & 157 & 59 & 122 & 109 & 95 & 95 & 98 & 126 \\
\hline 1998 & 98 & 83 & 104 & 104 & 98 & 120 & 91 & 123 & 92 & 101 & 59 & 107 \\
\hline 1999 & 56 & 85 & 107 & 139 & 116 & 106 & 110 & 88 & 102 & 92 & 109 & 110 \\
\hline 2000 & 89 & 63 & 97 & 119 & 105 & 127 & 112 & 97 & 93 & 94 & 103 & 116 \\
\hline 2001 & 80 & 67 & 94 & 85 & 99 & 132 & 153 & 84 & 86 & 112 & 126 & 67 \\
\hline 2002 & 92 & 51 & 96 & 100 & 100 & 109 & 134 & 113 & 92 & 123 & 124 & 67 \\
\hline 2003 & 79 & 63 & 113 & 83 & 102 & 101 & 117 & 119 & 106 & 115 & 106 & 82 \\
\hline 2004 & 88 & 88 & 92 & 96 & 120 & 88 & 127 & 85 & 97 & 115 & 105 & 106 \\
\hline 2005 & 89 & 71 & 96 & 94 & 124 & 109 & 97 & 110 & 102 & 106 & 83 & 117 \\
\hline 2006 & 73 & 81 & 78 & 112 & 109 & 127 & 106 & 99 & 98 & 91 & 107 & 124 \\
\hline 2007 & 92 & 72 & 91 & 82 & 87 & 117 & 112 & 131 & 109 & 101 & 97 & 98 \\
\hline 2008 & 86 & 92 & 68 & 93 & 107 & 113 & 119 & 146 & 132 & 99 & 101 & 75 \\
\hline 2009 & 79 & 45 & 74 & 91 & 91 & 111 & 130 & 112 & 115 & 85 & 90 & 126 \\
\hline 2010 & 73 & 96 & 81 & 118 & 116 & 110 & 119 & 105 & 91 & 112 & 88 & 107 \\
\hline 2011 & 100 & 77 & 85 & 99 & 89 & 102 & 113 & 116 & 96 & 101 & 111 & 111 \\
\hline 2012 & 89 & 75 & 83 & 96 & 103 & 126 & 108 & 90 & 98 & 89 & 117 & 102 \\
\hline 2013 & 101 & 104 & 85 & 86 & 124 & 101 & - & - & - & - & - & - \\
\hline MÍ & 83.2 & 77.4 & 91.8 & 97.0 & 103.3 & 106.3 & 117.8 & 107.5 & 104.4 & 100.0 & 104.2 & 105.9 \\
\hline DMİ & 83.3 & 77.4 & 91.9 & 97.1 & 103.4 & 106.5 & 117.9 & 107.7 & 104.5 & 100.1 & 104.3 & 106.0 \\
\hline
\end{tabular}

Aylık Mevsim İndeksi: [(Yt/12'şerli Hareketli Ortalamalar)x100] işlemiyle gözlem değerlerinden eğilim ve konjonktürün etkisi arındırılarak mevsim ve arızi faktörlerin etkisi ortaya çıkartılmıştır.

MI: Mevsim indeksi. Örnek: Ocak ayı Mİ hesaplama; ocak ayları Mİ değerleri toplamı / (n-1) yıl = 83.2, $\mathrm{n}=22$.

Mí Katsayısı: $=(1200) / \sum_{i=1}^{12} M \dot{I_{i}}=1200 / 1198.818=1.001$

DMI: Düzeltilmiş Mevsim İndeksi (DMİ) $=($ Mİ)(MIK)

Tablo 7: Maden Sektörü İhracatına

Konjonktür ve Arızi Faktörler Etkisi (KA) (\%)

\begin{tabular}{lrrrrrrrrrrrr}
\hline & \multicolumn{10}{c}{$\mathbf{1 0}$} \\
\cline { 2 - 13 } & $\mathbf{1}$ & $\mathbf{2}$ & $\mathbf{3}$ & $\mathbf{4}$ & $\mathbf{5}$ & $\mathbf{6}$ & $\mathbf{7}$ & $\mathbf{8}$ & $\mathbf{9}$ & $\mathbf{1 0}$ & $\mathbf{1 1}$ & $\mathbf{1 2}$ \\
\hline $\mathbf{1 9 9 2}$ & 93 & 65 & 63 & 53 & 60 & 64 & 69 & 44 & 96 & 54 & 70 & 54 \\
$\mathbf{1 9 9 3}$ & 62 & 52 & 55 & 52 & 55 & 49 & 82 & 94 & 52 & 92 & 91 & 77 \\
$\mathbf{1 9 9 4}$ & 61 & 88 & 95 & 78 & 61 & 76 & 65 & 98 & 107 & 92 & 121 & 126 \\
$\mathbf{1 9 9 5}$ & 99 & 102 & 111 & 125 & 90 & 117 & 135 & 134 & 122 & 75 & 178 & 201 \\
$\mathbf{1 9 9 6}$ & 117 & 168 & 150 & 125 & 107 & 127 & 138 & 103 & 172 & 140 & 76 & 131 \\
$\mathbf{1 9 9 7}$ & 146 & 175 & 168 & 115 & 228 & 86 & 165 & 163 & 147 & 156 & 152 & 192 \\
$\mathbf{1 9 9 8}$ & 190 & 171 & 177 & 166 & 143 & 163 & 107 & 153 & 116 & 134 & 77 & 136 \\
$\mathbf{1 9 9 9}$ & 91 & 148 & 156 & 192 & 154 & 139 & 133 & 116 & 137 & 127 & 143 & 142 \\
$\mathbf{2 0 0 0}$ & 146 & 111 & 142 & 162 & 131 & 151 & 119 & 110 & 106 & 108 & 110 & 119 \\
$\mathbf{2 0 0 1}$ & 104 & 94 & 107 & 91 & 100 & 127 & 128 & 76 & 79 & 107 & 115 & 59 \\
$\mathbf{2 0 0 2}$ & 100 & 60 & 96 & 94 & 89 & 93 & 102 & 93 & 79 & 110 & 105 & 56 \\
$\mathbf{2 0 0 3}$ & 82 & 70 & 107 & 75 & 85 & 82 & 86 & 98 & 90 & 101 & 90 & 69 \\
$\mathbf{2 0 0 4}$ & 94 & 100 & 86 & 85 & 100 & 72 & 94 & 68 & 79 & 99 & 86 & 86 \\
$\mathbf{2 0 0 5}$ & 92 & 79 & 90 & 83 & 102 & 86 & 69 & 86 & 82 & 89 & 67 & 94 \\
$\mathbf{2 0 0 6}$ & 76 & 92 & 75 & 101 & 93 & 108 & 82 & 85 & 87 & 84 & 94 & 107 \\
$\mathbf{2 0 0 7}$ & 102 & 87 & 96 & 82 & 83 & 107 & 92 & 119 & 102 & 99 & 92 & 93 \\
\hline
\end{tabular}




\begin{tabular}{rrrrrrrrrrrrr}
\hline $\mathbf{2 0 0 8}$ & 105 & 121 & 76 & 99 & 107 & 108 & 100 & 130 & 117 & 90 & 86 & 61 \\
$\mathbf{2 0 0 9}$ & 82 & 49 & 68 & 78 & 74 & 91 & 100 & 98 & 107 & 86 & 92 & 131 \\
$\mathbf{2 0 1 0}$ & 99 & 141 & 100 & 140 & 130 & 119 & 115 & 111 & 97 & 123 & 89 & 103 \\
$\mathbf{2 0 1 1}$ & 121 & 99 & 91 & 100 & 84 & 93 & 93 & 103 & 88 & 96 & 102 & 102 \\
$\mathbf{2 0 1 2}$ & 106 & 94 & 88 & 96 & 98 & 117 & 91 & 85 & 97 & 92 & 118 & 101 \\
$\mathbf{2 0 1 3}$ & 127 & 140 & 97 & 94 & 126 & 99 & 93 & 94 & 100 & 95 & 102 & 93 \\
\hline
\end{tabular}

Not: $\mathrm{KA}=\left[\mathrm{Yt} /\left[\left(\mathrm{Y}^{\prime} \mathrm{t} \times \mathrm{DMI}\right) / 100\right]\right]$ x 100

\section{BULGULAR VE DEĞERLENDİRMELER}

Aşağıda yer alan Şekil 1 ve Şekil 2 Türkiye'nin madencilik sektörü ihracatına yıllık ve aylık KA faktörler etkilerini göstermektedir. Bu grafiğe göre yüz değerinden sapmalar yıllık ve aylık KA dalgalanmalarını göstermektedir.

Şekil 1: Yıllık Konjonktür Ve Arızi Faktörler Etkisi (1992-2013)

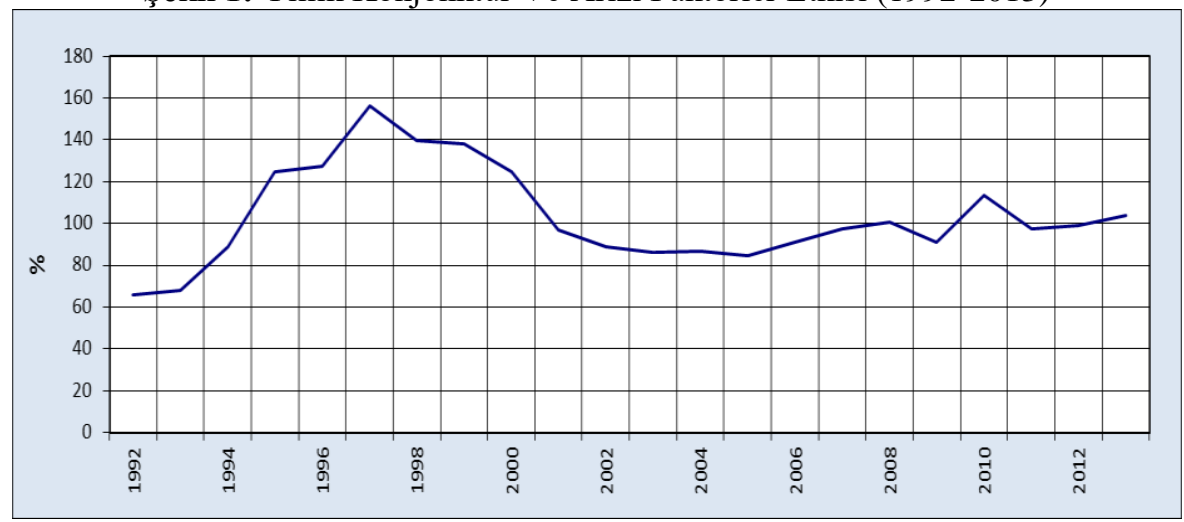

Şekil 2: Aylık Konjonktür ve Arızi Faktörler (KA) Etkisi (\%)

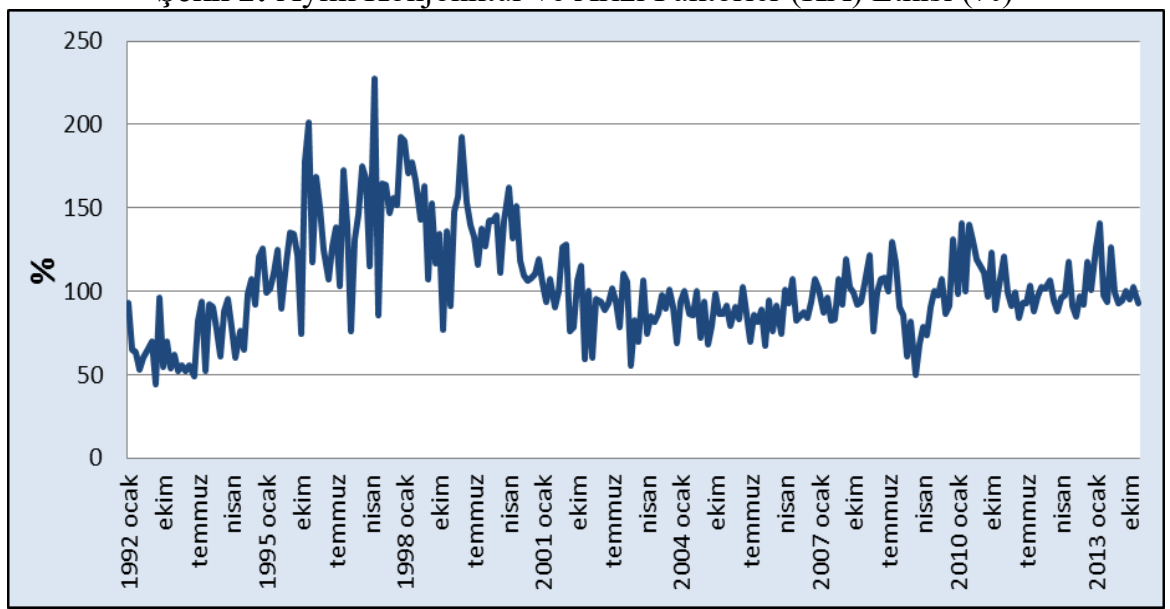

Genel olarak Türkiye'nin madencilik sektörü ihracatını yıllık olarak değerlendirdiğimizde; özellikle 1980'den günümüze devamlı bir artış göstermiş, 2000-2013 dönemi ihracattaki artış 1990-2000 döneminden, 1990-2000 dönemi 
ihracattaki artış ise 1980-1990 arası dönemdeki artıştan daha fazla olmuştur. 1990-2000 dönemindeki artışın en önemli nedenlerinden biri doğu bloğunun çökmesi ile bu ülkelerin uluslararası piyasada rekabet avantajını yitirmeleridir. Diğer yandan dünya ekonomisinde yaşanan canlanma ve uluslararası fiyatların yükselmesi maden ürünlerimize olan talebi artırmıştır. 90'lı yıllarda bu konjonktürden dolayı ihracat 500 milyon dolar gibi tarihin en yüksek seviyesine ulaşmıştır ve izleyen yıllarda artmaya devam etmiştir. 2000 yılında 517 milyon dolar olan ihracat ise 2013 yılında yüzde 400 artışla 2,64 milyar dolara çıkarak rekor kaydetmiştir.

Maden sektörü ihracatında konjonktürel etkilere baktığımızda ise özellikle 1990'da körfez savaşı gibi Dünya'nın beklemediği bir dış etkinin dünya ekonomisinde bir durgunluğa yol açtığını ve Türkiye'nin maden ihracatının da bu tarihten itibaren düșüșe geçtiğini görüyoruz. Bu düşüş 1993 y1lına kadar devam etmiş ve 1993 yılında maden ihracatı konjonktür etkisi ile 240 milyon dolara kadar düşmüştür. Körfez savaşı nedeni ile Türkiye çok büyük zararlara uğramıştır. Özellikle 1990'da geçilmesi planlanan ekonomik sistem başka bir tarihe ertelenmiştir. 1994 yılında Tansu Çiller'in Başbakanlığ 1 döneminde alınan istikrar tedbirleri ile yaşanan ekonomik sıkıntılar giderilmeye çalışılmıştır. 5 Nisan kararları denilen bu tedbirler ile TL'nin değeri düşürülmüş yani devalüasyon yapılmıştır. Bu devalüasyon ile Türkiye'nin ödemeler bilançosunu düzeltmek hedeflenmiştir. 1994'ten sonra Dünya ekonomisinin tekrar canlanma dönemine girmesi ve Türkiye'nin almış olduğu ekonomik tedbirler maden ihracatının da tekrar artmasını sağlamıştır. Bu durum Şekil 1'de 1994'ten (280 milyon dolar) 2000 yılı ortalarına kadar (517 milyon dolar) artan yükselen bir konjonktürel dalgalanma şeklinde yansımıştır. Ancak 2000'li yıllar öncesi bu olumlu dalgalanmalara rağmen Türkiye'nin bir türlü ekonomik problemlerini çözememiş olması nedeni ile yaşadığı kısa dönemli ekonomik krizler maden ihracatını etkilemektedir. Şekil 1'de görüldüğü gibi 1997 ve 1999 yıllarında ortaya çıkan dalgalanmalar buna örnek verilebilir. 2000'li y1llardan sonra ise nispeten daha istikrarlı bir ekonomi yönetimi söz konusu olduğundan bu periyoddaki dalgalanmalar daha az gerçekleşmiştir.

Türkiye'nin madencilik sektörü ihracatını aylık olarak değerlendirdiğimizde ilk göze çarpan KA (Şekil 2) grafiğidir. Bu grafikten konjonktürel etkiler nedeniyle sektör ihracatının aylık olarak çok fazla dalgalandığ1 görülmektedir. Bu dalgalanmalar 1992-2000 arası periyodda nerede ise istikrar kazanmış ve bu 8 yıllık periyodda yaklaşık 20 önemli konjonktür evresi yaşanmıştır. Bu durum, özellikle bu dönemde maden ihracatının birçok faktörden etkilendiğinin ve bir türlü istikrara kavuşamadığının bir göstergesidir. $\mathrm{Bu}$ dönemde dünyada 1990 körfez savaşı ve bunun uzun dönemli etkileri, 1997'de Asya kıtasında başlayan ve dalga dalga ülke ekonomilerine yayılan Asya borç krizi ve 1998 Rusya krizi bu şiddetli dalgalanmalara yol açan en önemli faktörlerden bazılarıdır. Dünyada ortaya çıkan bu tür siyasi ve ekonomik gelişmeler doğası gereği önceden öngörülemeyen ve Türkiye'nin iç ekonomik politikalarından bağımsız meydana gelen başlıca küresel ekonomik krizlere yol 
açmıştır. Bu krizler nedeniyle Türkiye maden sektörü ihracatının önemli ölçüde etkilendiği söylenebilir. Şekil 2'den de görüldüğü gibi bu etkilenme Türkiye açısından bazen olumlu bazen de olumsuz olmuştur. Ancak Türkiye'nin maden ihracatında bu dönemde gerçekleşen dalgalanmaları sadece bu krizler ile açıklamak çok zordur. Özellikle Türkiye'nin yapısal sorunları ve bu sorunların yaratmış olduğu ekonomik problemlerin niteliği (dış kaynak bağımlılığı, enflasyonist baskılar, rekabet eksikliği, devletin ekonomideki ağır rolü, ekonomik büyümede imalat sanayinin öncülüğü elinden kaçırmış olması vb.) bu dönemde ihracatı etkileyen diğer içsel önemli faktörlerdir. 1994 yılında Türkiye ekonomisinde yaşadığımız ekonomik kriz bunlardan bir tanesidir. Bir diğeri de Türk ekonomisinin dış rekabete açılması ve devletin ekonomik varlığının küçültülmesi gibi konularda bu dönemde gerekli yapısal reformların yapılamamasidir.

Maden ihracatına ilişkin 2000 yılı sonrası aylık konjonktürel dalgalanmaların daha önceki dönemlere göre nispeten azaldığı görülmektedir. Bunun en önemli nedenlerinden birinin Türkiye'de 2000 y1lı sonrasinda uygulanan ekonomik istikrar programları olduğu söylenebilir. Şekil 1 ve 2 incelendiğinde 2000 y1lı sonrası gerçekleşen önemli bir konjonktürel dalgalanma göze çarpmaktadır. Bu dalgalanma 2008 y1lı Eylül ayında başlamakta ve 2010 yılına kadar devam etmektedir. Bu dönemde maden ihracatı yaklaşık yüzde 22 oranında azalmıştır. Bu dalgalanmanın nedeninin, 2008 yılı Eylül ayında Amerika Birleşik Devletleri'nde ortaya çıkan ve dünyanın birçok ekonomisini olumsuz yönde etkileyen küresel finansal krizdir.

Şekil 3 ve 4 Türkiye maden sektörü ihracatının 1992-2013 arası yıllık ve aylık eğilim ve reel ihracat değerlerini göstermektedir.

Şekil 3: Y1llık Tahmini Eğilim ve Reel İhracat (1992-2013)

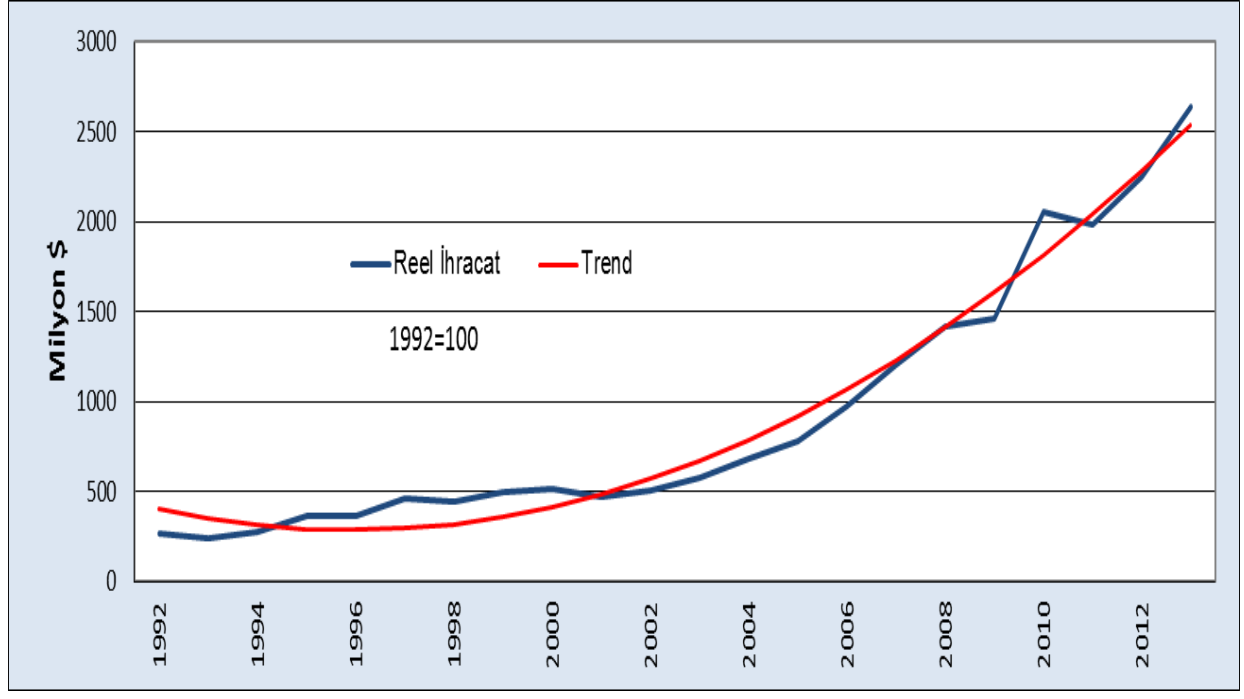


Şekil 4: Aylık Tahmini Eğilim ve Reel İhracat (1992-2013)

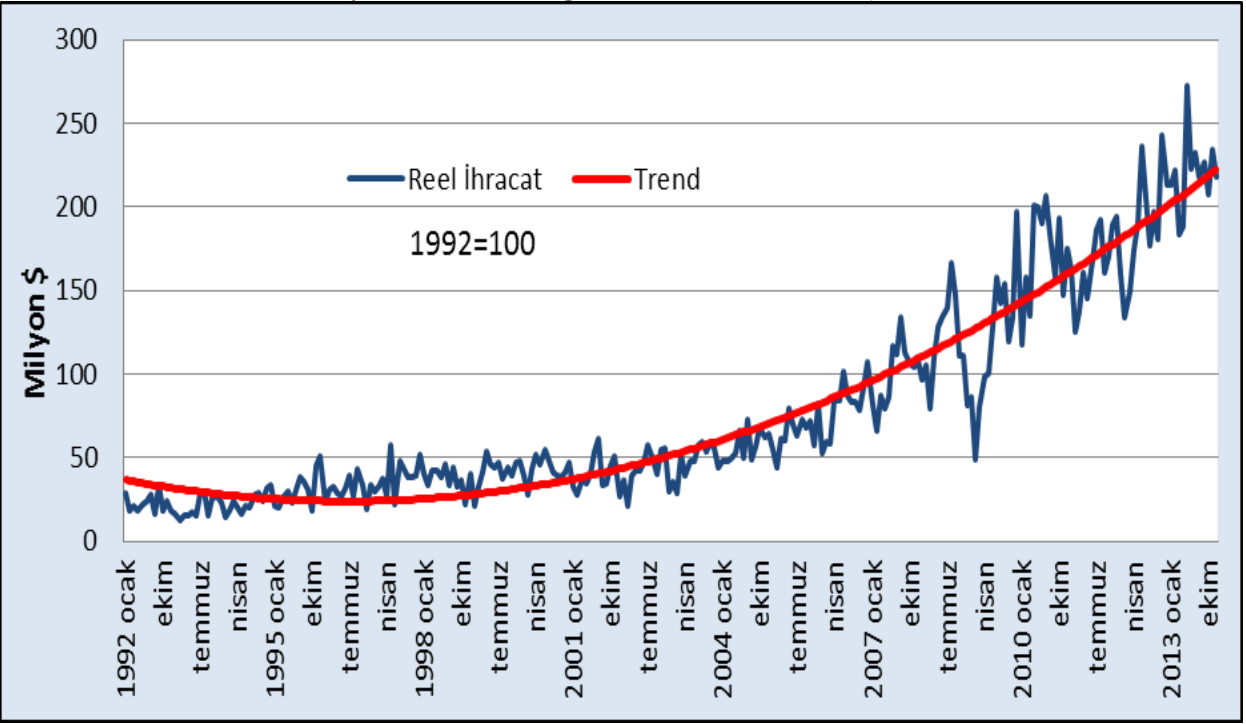

Maden ihracatının yıllık eğilim grafiğini incelediğimizde, ihracatın 1992 yılından (406 milyon dolar) 1996 yılı ortalarına kadar (287 milyon dolar) yaklaşık yüzde 30 azaldığını görmekteyiz. İhracat 1996 ve 2000 yılları arası yatay bir seyir izlemiş (ortalama 330 milyon dolar), bu tarihten sonra ise 2013 yılına kadar sürekli artan bir oranda (yıllık yüzde 11 ile yüzde 18) yükselmiştir. 2013 y1lı madencilik sektörü reel ihracatı 2,64 milyar dolar ile rekor kırmıştır. Yaşanan kısa dönemli dalgalanmalara rağmen Türkiye’nin maden ihracatı artan bir eğilim göstermiştir.

Maden ihracatının aylık eğilim grafiğini incelediğimizde, ihracatın 1992 yılından 1996 yılı ortalarına kadar azaldığını görmekteyiz (aylık ortalama 25 milyon dolar). İhracat 1996 ve 2000 yılları arası yatay bir seyir izlemiş (ortalama 32 milyon dolar), bu tarihten sonra ise 2013 yilına kadar artan bir oranda yükselmiştir (ortalama 140 milyon dolar). Bu periyod da, Türkiye’nin uyguladığ1 ekonomik politikalar ile dünyada yaşanan ekonomik gelişmelerin etkileri önemlidir. 2000 yılında uygulanmaya başlanan çapa politikası (kur rejiminin enflasyon hedefine yönelik uygulanması) başarısız olmuş yani kur ile enflasyon arasındaki makas açılmış ve TL aşırı değer kazanmıştır. Bu durum neticesinde ihracat mallarımıza olan talep azalmıştır. Bu, zaten 1997 Asya ve 1998 Rusya krizleri ile dünyada kendini gösteren durgunluk ile de birleşince özellikle sanayi üretiminde önemli rolü olan maden ihracatımız azalmıştır. Diğer yandan da ithalatımız artış kaydetmiştir. Sonuçta bu periyodda Türk ekonomi tarihinin en büyük dış ticaret açığı oluşmuştur. Bunun sürdürülemeyeceği anlaşılınca çapa politikasından vazgeçilerek 23 Şubat 2001 günü serbest döviz kuru rejimi uygulamasına geçilmiştir. Serbest döviz kuru uygulamasına geçilir geçilmez, TL uluslararası paralara karşı değer kaybetmiştir. Sonuçta değer kaybeden TL ile izleyen dönemde ihracat artmış ve ithalat azalmış, böylece ödemeler dengesinde ki açık kapanmıştır. 2001 yılı sonrası ihracat eğiliminin sürekli arttığı 
görülmektedir. Bunda en önemli etkenin Türkiye'de 2000 yılı sonrasında uygulanan ekonomik politikaların başarısı olduğu söylenebilir.

Zaman serisi modellerinde KA ve eğilim dışında etkili olan bir diğer faktör ise mevsimsel etkilerdir. Mevsimsel faktörlerin Türkiye madencilik sektörü ihracatı üzerine etkisi analiz ettiğimiz bir diğer konudur. Şekil 5 madencilik sektörü ihracatının eğilim ve konjonktür etkisinden arındırılmış düzeltilmiş mevsim indeksini göstermektedir. Şekil 5'te gözlenen önemli bir nokta maden ihracatının özellikle Temmuz ve Aralık aylarında arttığı, Şubat ve Ekim aylarında ise azaldığıdır. Mart, Nisan, Mayıs ve Haziran aylarında ise nispeten yatay bir seyir izlemektedir. Bu da maden ihracatının yaz ve kış aylarında arttığ 1 ilkbahar ve sonbahar aylarında ise azaldığı anlamına gelmektedir.

Șekil 5: Düzeltilmiș Mevsim İndeksi

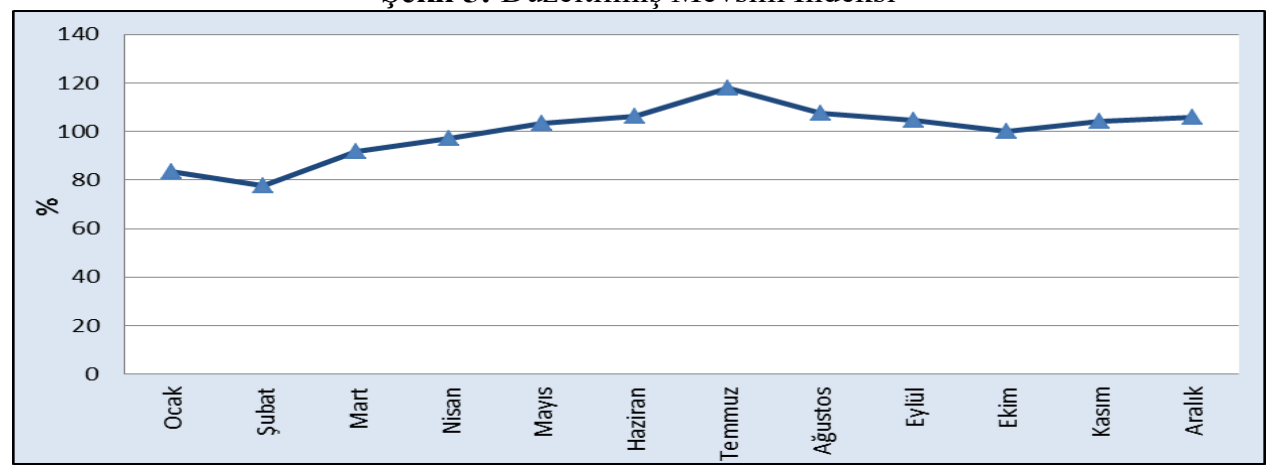

\section{SONUÇ VE POLITTIKA ÖNERILERİ}

1992-2013 dönemi zaman serisi analizine dayalı bulgular madencilik sektörü ihracatının konjonktürel etkiler nedeniyle kısa dönemde çok fazla dalgalandığını ve bu dalgalanmaların özellikle 2000 yılı öncesi dönemde istikrar kazandığını ortaya koymaktadır. Bu durum, Türkiye maden sektörü ihracatının hem içsel hem de dişsal birçok siyasi ve ekonomik faktörden etkilendiğinin ve bir türlü istikrara kavuşamadığının bir göstergesidir. Bu durum, literatür araştırması bölümünde değindiğimiz üzere, Türkiye'de çeşitli ekonomik değişkenler üzerine gerek ampirik gerekse politik konjonktürel dalgalanmalar konusunda yapılan çalışmaların bulguları ile örtüşmektedir. Özellikle 2000'li yıllar öncesi dışsal faktörlerden ziyade Türkiye'nin ekonomik problemlerini çözememiş olması nedeniyle yaşadığı kısa dönemli ekonomik krizler maden ihracatını daha fazla etkilemektedir. Türkiye ekonomisinin yapısal sorunları ve bu sorunların yaratmış olduğu ekonomik problemlerin niteliği, Türk ekonomisinin dış rekabete açılamaması, özelleştirmeye ilişkin gerekli yapısal reformların yapılamaması ihracatı etkileyen en önemli içsel faktörlerdir. 1994 yılında Türkiye ekonomisinde yaşadığımız ekonomik kriz, 1997 ve 1999 yıllarında ortaya çıkan dalgalanmalar bunlardan birkaç tanesidir. 2000'li y1llardan sonra ise nispeten daha istikrarlı ve başarılı bir ekonomi yönetimi söz konusu olduğundan konjonktürel dalgalanmalar daha az gerçekleşmiştir. 2000 sonrası yaşanan en önemli konjonktürel dalgalanma 
dışsal nitelikte olan 2008 küresel finansal krizi ve neticesinde madencilik sektörü ihracatının 2010 yılına kadar yüzde 22 düşmesidir. Ancak, analiz bulgularına göre, yaşanan kısa dönemli konjonktürel dalgalanmalara rağmen Türkiye madencilik sektörü ihracatı (özellikle 2002 yılı sonrasından günümüze) artan bir eğilim göstermiştir.

İhracat genel olarak bir ülkenin milli gelirinden bağımsızdır. İhracatı belirleyen temel iki faktör ihracat yapılan ülkenin milli geliri ve uluslararası fiyatların ülke içi fiyatlara oranıdır. İhracat bu faktörler ile doğru orantılı bir şekilde artar. Ancak ihracatı sadece bu faktörler belirlemez. Bunlar dışında ülke içi faktörler olarak adlandırdığımız ülkenin ekonomi politikaları, ülkede yaşanan ekonomik krizler, dişsallıklar vb. faktörlerde ihracat üzerinde etkili olur. Birde genel anlamda dünyada ki ekonomik koşullar çok önemlidir. Özellikle dünyadaki ekonomik durum ve gelecekteki beklentiler ihracat üzerinde önemli rol oynar. Günümüzde teknoloji ve küreselleşme neticesinde ülke ekonomileri birbirlerine bağımlı hale gelmişlerdir. Bir ülkede yaşanan herhangi bir kriz az veya çok diğer ülkeleri de etkilemektedir. Eğer bu ülke Amerika Birleşik Devletleri, Çin, Almanya gibi gelişmiş bir ülke ise o zaman bu yerel kriz bir dünya krizine bile dönüşebilmektedir. Dolayısı ile dışa açık ve küresel ekonomiye bütünleşmiş Türkiye ekonomisi de bütün bu faktörlerden olumlu veya olumsuz etkilenmektedir. Uluslararası piyasada istikrarlı bir şekilde yer almak ve konjonktürel dalgalanmalardan daha az etkilenmek istiyorsak ihraç mallarımızın talep esnekliğini azaltmak zorundayız. Bu da daha fazla Ar-Ge, yenilik, kalite, rekabet gücü, katma değer, verimlilik ve çeşitlilik ile mümkündür. Bunları sağladığımız ölçüde dış kaynaklı krizleri ve konjonktürel dalgalanmaları en az zararla atlatır, ekonomik büyüme ve gelişmemizi sağlam temellere dayandırmış oluruz. Bu çerçevede, madencilik sektöründe hammadde üretimi ve dış satımına dayalı bir pazar anlayışından kurtulup, dünya pazarlarında katma değeri yüksek, işlenmiş, kalite ve alternatifi olmayan teknolojik madencilik ürünlerinin üretilmesi gerekmektedir. 
Ek 1: Aylık Reel İhracat Değerlerinin 12'şerli Hareketli Ortalamaları (Milyon \$, 1992=100)

\begin{tabular}{|c|c|c|c|c|c|c|c|c|c|c|c|c|}
\hline \multirow[b]{2}{*}{ Yil } & \multicolumn{11}{|c|}{$\mathbf{A y}$} & \multirow[b]{2}{*}{12} \\
\hline & 1 & 2 & 3 & 4 & 5 & 6 & 7 & 8 & 9 & 10 & 11 & \\
\hline 1992 & & & - & - & 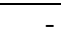 & & 22 & 21 & 21 & 20 & 20 & 19 \\
\hline 1993 & 19 & 20 & 20 & 19 & 20 & 20 & 20 & 20 & 21 & 21 & 22 & 22 \\
\hline 1994 & 22 & 21 & 22 & 22 & 22 & 23 & 24 & 24 & 24 & 25 & 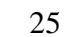 & 26 \\
\hline 199 & 27 & 28 & 28 & 28 & 29 & 30 & 31 & 31 & 32 & 32 & 2 & 33 \\
\hline 1996 & 33 & 32 & 33 & 34 & 33 & 31 & 31 & 31 & 31 & 32 & 53 & 34 \\
\hline 1997 & 34 & 3 & 35 & 35 & 36 & 38 & 39 & 40 & 0 & 41 & 40 & 41 \\
\hline 1998 & 41 & 41 & 40 & 40 & 39 & 38 & 37 & 36 & 36 & 36 & 37 & 37 \\
\hline 1999 & 38 & 38 & 38 & 39 & 40 & 41 & 42 & 43 & 43 & 43 & 43 & 43 \\
\hline 2000 & 44 & 44 & 44 & 44 & 43 & 43 & 43 & 43 & 42 & 41 & 40 & 40 \\
\hline 2001 & 41 & 41 & 40 & 40 & 41 & 41 & 40 & 40 & 40 & 40 & 40 & 40 \\
\hline 2002 & 40 & 40 & 41 & 42 & 42 & 43 & 43 & 43 & 44 & 44 & 44 & 45 \\
\hline 2003 & 45 & 45 & 46 & 47 & 47 & 48 & 49 & 50 & 51 & 51 & 53 & 53 \\
\hline 2004 & 54 & 54 & 54 & 55 & 55 & 56 & 57 & 58 & 58 & 59 & 59 & 61 \\
\hline 2005 & 61 & 6 & 63 & 64 & 64 & 64 & 65 & 66 & 66 & 67 & 68 & 70 \\
\hline 2006 & 72 & 73 & 75 & 76 & 77 & 80 & 82 & 84 & 85 & 86 & 86 & 87 \\
\hline 2007 & $8 \varepsilon$ & 91 & 95 & 97 & 99 & 99 & 100 & 102 & 04 & 105 & 108 & 110 \\
\hline 2008 & 11 & & 117 & 119 & 119 & 118 & 117 & 114 & 112 & 111 & 110 & 108 \\
\hline 2009 & 10 & 10 & 108 & 109 & 110 & 116 & 122 & 128 & 135 & 141 & 150 & 156 \\
\hline 2010 & & & 10 & 170 & 173 & 173 & 174 & 174 & 173 & 172 & 168 & 164 \\
\hline 2011 & & & 163 & 162 & 163 & 165 & 166 & 166 & 167 & 168 & 170 & 175 \\
\hline 2012 & 179 & 179 & 180 & 182 & 184 & 187 & 190 & 196 & 201 & 203 & 207 & 210 \\
\hline 2013 & 211 & 214 & 217 & 219 & 220 & 220 & - & 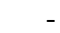 & - & - & - & \\
\hline
\end{tabular}

Not: İlk değer 1992 y1lı temmuz ayı 12'şerli hareketli ortalama değerdir ve şu şekilde hesaplanmıştır: $\mathrm{Y}^{\prime}{ }_{\text {Temmuz1992 }}=[(28 / 2+18+21+\ldots \ldots \ldots .+24+18+16 / 2)] / 12$

\section{KAYNAKÇA}

Açıkgöz, Ş. (2008). An Analysis of Business Cycles under Regime Shifts: The Turkish Economy and Industrial Sector. D.E.Ü. I.I. B.F, 23(2), 135-151.

Akçoraoğlu, A. ve Yurdakul, F. (2004). Siyasal Ekonomi Açısından Büyüme, Enflasyon ve Bütçe Açıkları: Türkiye Üzerine Bir Uygulama. Siyasal Bilgiler Fakültesi Dergisi, 59(1), 1-25.

Akgül, I., Koç, S. ve Koç, S. Ö. (2007). Cari İşlemler Dengesi Rejim Değişim Modelleri ile Modellenebilir mi? 8. Türkiye Ekonometri ve İstatistik Kongresi, Malatya.

Alizadeh, A. H., Nomikos, N. K. ve Pouliasis, P. K. (2008). A Markov Regime Switching Approach for Hedging Energy Commodities. Journal of Banking \& Finance, 32, 1970-1983.

Altuğ, S. ve Bildirici, M. (2010). Business Cycles around the Globe: A Regime Switching Approach. Çalışma Metni, no: 1009, TÜSİAD-Koç Unıversity Economic Research Forum Working Paper Series.

Aydoğuş, O., Türkcan, B., Çalışkan, E. T. ve Kopurlu, B. S. (2009). Kriz Teorileri: Kondratieff, Schumpeter ve Wallerstein. Çalışma Metni, Ege University Working Papers in Economics.

Barro, R. J. (1995). Inflation and Economic Growth. Çalışma Metni, NBER no: 5326, Cambridge, MA: National Bureau of Economic Research.

Bazdrescha, S. ve Wernerb, A. (2005). Regime Switching Models for the Mexican Peso. Journal of International Economics, 65, 185-201.

Bildirici, M. ve Bozoklu, Ü. (2010). Beklentilerin Ekonomi Üzerindeki Etkileri: MS-VAR Yaklaşımı. Çalışma Metni, TÜSİAD-KOÇ University Economic Research Forum, 1019.

Bilgili, F., Tülüce, N. S. H. ve Doğan, İ. (2012). The Determinants of FDI in Turkey: A Markov Regime-Switching Approach. Economic Modelling, 29, 1161-1169.

Boratav, K. (1988). Türkiye İktisat Tarihi, 1908-1985. 1.Bask1, İstanbul: Gerçek Yayınevi. 
Burns, A. F. ve Mitchell W. C. (1946). Measuring Business Cycles. New York: NBER.

Diebold, F. X. ve Rudebusch, G. (1996). Measuring Business Cycles: A Modern Perspective. Review of Economics and Statistics, 78, 67-77.

Doğruel, A. S. (2002). Ístikrar Politikalarl ve Ekonomik Büyüme: Türkiye'nin Son Yirmi Yıllık Serüveni Üzerine Düşünceler. Küreselleşme Emek Süreçleri ve Yapısal Uyum, Türk Sosyal Bilimler Derneği, Ankara: İmaj Yayıncılık.

DPT. (2007). Dokuzuncu Kalkınma Planı 2007-2013, Madencilik Özel İhtisas Komisyonu Raporu (DPT:2739-ÖİK: 690), Ankara.

Ekonomi Bakanlığı. (2012). Sektör Raporları, Madencilik Sektörü. İhracat Genel Müdürlüğü Maden, Ankara: Metal ve Orman Ürünleri Daire Başkanlığı.

Enerji ve Tabii Kaynaklar Bakanlığı. (2013). 2014 Yılı Bütçe Sunumu. Ankara: Strateji Geliştirme Bakanlığı.

Fırat, E. ve Demirtaş, C. (2012). Konjonktürel Teoriler Işıı̆ı̆nda Türkiye'de Yaşanan 2000- 2001 Krizinin Değerlendirilmesi. Ekonomi Bilimleri Dergisi, 4(1), 23-32.

Fırat Kalkınma Ajansı. (2011). Bingöl İli Madencilik Potansiyeli Profili. 1-30.

Fischer, S. (1993). The Role of Macroeconomic Factors in Growth. Journal of Monetary Economics, 32(3), 485-512.

Haberler, G. (1937). Prosperity and Depression: A Theoretical Analysis of Cyclical Movements. Geneva: League of Nations.

Hansen, A. H. (1964). Business Cycle and National Income. New York: W.W. Norton Company.

Kabadayı, B. (2013). Türkiye Konjonktür Dalgalanmaları ve Rejim Değişimi Analizi. Uluslararası Yönetim İktisat ve İsletme Dergisi, 9(19), 107-120.

Kalkınma Bakanlığı. (2015). Onuncu Kalkınma Planı 2014-2018. Madencilik Politikaları, Özel İhtisas Komisyonu Raporu, Ankara.

Karabulut, G. (2005). Konjonktürün Dönüm Noktalarının Tahmini için Bir Probit Modeli: Türkiye Örneği. D.E.Ü. I.I.I.B.F. Dergisi, 20(2), 1-9.

Kartalkanat, A. (1991). Cumhuriyet Döneminde Madenciliğimizin Gelişimi ve Türkiye Madencilik Politikası. Jeoloji Mühendisliği, 38, 51-67.

Kazmier, L. (2003). Schaum's Outline of Business Statistics. 4.Bask1, USA: McGraw-Hill.

Kepenek, Y. (1987). Gelişimi, Üretim Yapısı ve Sorunlarıly Türkiye Ekonomisi. 4.Bask1, Ankara: Teori Yayınları.

Kepenek, Y. ve Yentürk, N. (2011). Türkiye Ekonomisi. 24.Bask1, İstanbul: Remzi Kitapevi.

Kesgingöz, H. (2014). Türk Sanayisinin Konjonktürel Analizi. AKÜ İ̈BF Dergisi, 16(1), 155-166.

Kondratieff, N. D. ve Stolper, W. F. (1935). The Long Waves in Economic Life. The Review of Economics and Statistics, 17(6), 105-115.

Kuznets, S. (1930). Secular Movements in Production and Prices: Their Nature and Bearing on Cyclical Fluctuations. Cambridge: MA: Harvard University Press.

Liboshi, H. (2007). Duration Dependence of the Business Cycle in Japan: A Bayesian Analysis of Extended Markov Switching Model. Japan and the World Economy, 19, 86-111.

Mann, P. (1995). Statistics for Business and Economics. New York: Wiley.

Mill, J. S. (1909). Principles of Political Economy (1848). Publisher Longmans, Green and Co.

Moolman, E. (2004). A Markov Switching Regime Model of the South African Business Cycle. Economic Modelling, 21, 631-646.

Moore, T. ve Wang, P. (2007). Volatility in Stock Returns for New EU Member States: Markov Regime Switching Model. International Review of Financial Analysis, 16, 282-292.

MTA. (1985). Türkiye'de Madenciliğin Tarihçesi ve MTA. MTA Genel Müdürlüğü yayını, Ankara: MTA Matbaas1.

Nefçi, S. N. (1984). Are Economic Time Series Asymmetric over the Business Cycle? Journal of Political Economy, 92(2), 307-328.

Onur, S. (2001). Politik Konjonktür Dalgalanmaları ve Türkiye Uygulamas1 (1950-2000). Süleyman Demirel Üniversitesi Iktisadi ve İdari Bilimler Fakültesi Dergisi, 6(2), 157-184.

Özer, M. ve Taban, S. (2006). Modern Konjonktür Teorileri. Bursa: Ekin Kitabevi. 
Özkan, F. ve Tarı, R. (2010). Türkiye'de 1980 Sonrası Seçim Dönemlerinin Politik Konjonktürel Dalgalanmaları Teorisi Çerçevesinde Analizi. Erciyes Üniversitesi İktisadi ve İdari Bilimler Fakültesi Dergisi, 36-224, 223-238.

Pigou, A. C. (1927). Industrial Fluctuations. London: Macmillan.

Sayan, S. ve Berument, H. (1997). Türkiye'de Siyaset Ekonomik Popülizm ve Hükümetler. Hacettepe Üniversitesi IISSBF Dergisi, 15(2), 171-185.

Schumpeter, J. A. (1939). Business Cycles A Theoretical, Historical and Statistical Analysis of the Capitalist Process. New York: McGraw Hill.

Sezgin, Ş. (2007). Türkiye'de Politik Konjonktürel Dalgalanmalar: 1950-2003 Dönemi. Ankara Üniversitesi SBF Dergisi, 62(2), 135-154.

Tamzok, N. (2005). Türkiye Madencilik Sektöründe Yapısal Dönüşüm ve Sonuçları. Türkiye 19. Uluslararası Madencilik Kongresi ve Fuarı, IMCET 2005, 9-12 Haziran 2015, İzmir, 520.

Tamzok, N. (2008). Osmanlı İmparatorluğu'nun Son Döneminden Çok Partili Döneme Madencilik Politikaları, 1861-1948. Ankara Üniversitesi SBF Dergisi, 63(4), 179-204.

Tarı, R. ve Kumcu, F. S. (2005). Türkiye'de İstikrarsız Büyümenin Analizi (1983-2003 Dönemi). Kocaeli Üniversitesi Sosyal Bilimler Enstitüsü Dergisi, 9(1), 156-179.

TBMM. (2010). TBMM Madencilik Araştırma Komisyon Raporu. Madencilik Sektöründeki Sorunların Araştırılarak Alınması Gereken Önlemlerin Belirlenmesi Amacıyla Kurulan Meclis Araştırması Komisyonu Raporu (Dönem :23, Yasama Yılı: 4, s.sayısı: 544), Ankara.

TMMOB. (2011). Madencilik Sektörü ve Politikaları Raporu. Maden Mühendisleri Odası.

TOBB. (2008). Türkiye Madencilik Sektör Raporu. TOBB Madencilik Sektör Meclisi, No: 2008/77.

Turan, M. (1981). Madenciliğimizin, Tarihsel Gelişimi. Türkiye-Madencilik Bilimsel ve Teknik 7. Kongresi Tebliğler Kitabı. 16-20 Şubat 1981, Ankara: TMMOB Maden Mühendisleri Odasi yayını.

Turan, M. (1983). Madenciliğimizin Tarihsel Gelişimi, Cumhuriyet Dönemi Türkiye Ansiklopedisi. İstanbul: İletişim Yayınları.

Uygur, E. (2000). Erratic Growth and Investment Behavior in Turkey. Turkey: Country Economic Memorandum, Structural Reforms for Sustainable Growth. 20657, vol.1, Washington: The World Bank.

Weiers, R. M. (2007). Introduction to Business Statistics. 6.Bask1, South-Western College Pub, USA: Thomsan South-Western.

Yamak, N. ve Topbaş, F. (2008). Stok Yatırımları ve Konjonktürel Dalgalanmalar. 2. Ulusal İktisat Kongresi, İzmir.

Yeldan, E. (1996). Kısa Vadeli Sermaye Akımları. Ekonomide Durum, 1, 41-48. 


\section{SUMMARY}

The main purpose in this paper is to reveal the cyclical fluctuations occurred in the Turkish mining industry's exports over the 1992-2013 periods and to analyze the internal and external economic factors behind these fluctuations. Also, general information about the development process of the industry which is one of the most important industries of world economy is given and growing process of the industry's export in Turkey is being evaluated. No similar empirical study based on the cyclical fluctuations on the export of mining industry in Turkey has been encountered in the literature. The cyclical fluctuations experienced in the industry's exports, however, is rather important when considering the contribution of this industry to the country's national income and employment. The study is designed as follows. Firstly, theoretical and empirical literature on cyclical fluctuations is examined, then, historical development process and structure of the industry in Turkey are evaluated and various statistics on the production and export of the industry are presented. Thirdly, by using monthly and yearly time series data related to industry's export, the estimated trend function is calculated by performing linear and quadratic regression analyses by the method of ordinary least squares. Lastly, by evaluating the findings obtained in the third section, results and policy recommendations are conducted. The results revealed that the estimated export trend function is a quadratic. According to the findings, it seems that the export of the industry rises and falls irregularly, it is also seen that these fluctuations have gained the stability especially for the pre- 2000 period. This situation indicates that the export of the industry is affected from both internal and external many political and economic factors and that somehow it has been unable to stabilize in this period. After the 2000s, due to relatively stable and successful economic management, internal cyclical fluctuations are occurred at a lower level. The most important cyclical fluctuation occurred in this period (after 2000s) is 2008 global financial crisis, which is an external phenomenon; in subsequent two years the export of the Turkish mining industry declined 22 percent. However, the findings reveal that exports of the industry has shown an increasing trend especially after 2002, despite the short-term cyclical fluctuations experienced. 